\title{
State Supreme Courts: A Century of Style and Citation*
}

\author{
Lawrence M. Friedman, Robert A. Kagan, Bliss \\ Cartwright, and Stanton Wheeler $\dagger$
}

Appellate court opinions, carefully indexed and preserved in law libraries, are a tremendous resource for historians and social scientists. In the theory of the common law, these opinions are the law; they stand in the center of the legal system. Their power is enhanced by the common law doctrine that links them in a chain of influence and causation - the doctrine of precedent. Their precedential value means that they are also powerful resources for the practicing lawyer-often the basic material with which he works.

But these appellate opinions also are crucial documents for any study of judicial culture. The reasoning of the judges, over the years, reveals judges' notions of law and of the judicial role; it is an essential window into the legal culture of the judges. The style of opinions is as good an indicator as we have of what counts as sound legal reasoning for any given era. Even objective aspects of judicial opinions can be revealing, as Merryman's studies of California citation since 1950 and Goutal's work on opinion length show. ${ }^{1}$ Moreover, a more policy-oriented conception of the judicial role arguably could be re-

* Work on this article was supported by NSF Grant No. GS-384-13. The authors would like to thank everyone who assisted and advised them in gathering and analyzing the data set forth in this article and add our particular thanks to Professor John P. Hartigan (Statistics Department, Yale University), Diana Polise Garra, Peter Harris, and James Meeker.

$\dagger$ The authors are, respectively, Lawrence M. Friedman, Marion Rice Kirkwood Professor of Law, Stanford University; Robert A. Kagan, Associate Professor of Political Science, University of California, Berkeley; Bliss Cartwright, Associate Professor of Law, State University of New York at Buffalo; Stanton Wheeler, Professor of Law and Sociology, Yale University.

1. Merryman, Toward a Theory of Citations: An Empirical Study of the Citation Practice of the Califomia Supreme Court in 1950, 1960 and 1970, 50 S. CAL. L. REv. 381 (1977) [hereinafter cited as Merryman, Toward a Theory of Citations]; Merryman, The Authority of Authorily: What the Califomia Supreme Courl Cited in 1950, 6 STAN. L. REv. 613 (1954) [hereinafter cited as Merryman, The Authorily of Authority]; Goutal, Characteristics of Judicial Slyle in France, Britain and the U.S.A., 24 AM. J. COMP. L. 43 (1976). 
flected in another "objective" facet of appellate opinions-a higher incidence of dissenting and separate concurring opinions, as has been evident for some years in the output of the U.S. Supreme Court.

Over the years, there has been a good deal of speculation about changes in judicial style, but, with the exception of the work of Merryman and Goutal, surprisingly little gathering of hard data. This article attempts to fill some of the gaps. We will analyze changes in American court opinions, using quantitative information that can serve as a rough indicator of shifts in judicial style. We draw on a sample of 5,900 cases from 16 state supreme courts (SSCs). Our data span a century of time, from 1870 to 1970. In this article, we present findings about opinion length, dissents and concurrences, and citation patterns. We also explore interstate differences, to shed some light on the possible determinants of changes over time.

\section{RESEARCH METHOD}

To pick our sample of 16 SSCs, we first excluded Hawaii and Alaska, which became states only toward the end of our 100-year period. We then divided the remaining 48 states into five clustersgroups of states that were most alike, for most of the 100-year period-using variables such as population, industrialization, urbanization, per capita income, racial composition, legislative innovativeness, and other measures that seemed likely to affect the legal business of a state court system. ${ }^{2}$ One cluster that emerged was made up of Plains states, such as Kansas, Nebraska, and the Dakotas; another consisted 'of urban, industrialized states; a third cluster included the Southern states; the Rocky Mountain states fell into another distinct cluster. From each cluster we selected states randomly, in proportion to the size of the cluster. The 16 SSCs we ended up with were (alphabetically): Alabama, California, Idaho, Illinois, Kansas, Maine, Michigan, Minnesota, Nevada, New Jersey, North Carolina, Oregon, Rhode Island, South Dakota, Tennessee, and West Virginia.

We counted all published SSC opinions of at least one page in length issued in 21 sample years-1870, 1875, 1880, and so on through 1970 - for each of these states. From each sample year, we

2. The measures taken were from census data assembled by Richard Hofferbert and made available through the University of Michigan Consortium. See Hofferbert, Socio-Economic Dimensions of the American States: 1890-1960, 12 Midwest J. POL. ScI. 401 (1968). The measure of legislative innovativeness was developed by Jack Walker. See Walker, The Diffision of Innouations Among the American States, 63 AM. POL. SaI. REV. 880 (1969). 
drew a random sample of 18 cases per SSC-giving us a total of roughly 5,900.3 A member from a team of 10 law students read each case and recorded its procedural history, the nature of the parties, and the area of law underlying the plaintiff's claim. The student noted any constitutional issues, the court's decision, the presence of concurring or dissenting opinions, the length of the opinions and the authorities cited, and, finally, how often the case was subsequently cited in Shepard's citators. ${ }^{4}$ Twenty percent of the sampled cases were double-coded; hundreds more were reread and recoded when computer editing routines flashed signals of some possible coding error. We believe our method has produced a representative sample of cases, reliably coded. ${ }^{5}$

\section{The Length of State Supreme Court Opinions}

Changes in length of opinions over time may reveal changes in legal culture. Jean Louis Goutal has noted striking differences in the length of opinions written by French, American, and English judges in third-party-beneficiary contract cases. French cour de cassation opinions in the 1915-1944 period usually took up less than a page. American SSG opinions were about three times as long; they averaged almost three (small-type) pages. The English appellate opinions, however, averaged more than 12 pages. $^{6}$

3. Our target was a sample of roughly 6,000 cases (budget and time prevented anything much larger), which worked out to 18 cases at each of 21 sample years, for 16 states. The actual sample turned out to be 5,904 cases, because Idaho and South Dakota did not become states until 1890.

For the most part, we analyze and present the sampled data in three time periods1870-1900, 1905-1935, 1940-1970. In this form, the relevant sample size for each of the latter two periods is 126 cases per state and 2,016 for the 16 states. The sample size for the 16 states for the 1870-1900 period is 1,872. We sometimes use seven time periods-1870-1880, $1885-1895, \ldots, 1960-1970$ - in presenting national trend data, aggregating samples from the 16 SSCs. In this form, the sample size for each time period is 864 ( 756 for $1870-1880,828$ for 1885-1895).

4. We used 1975 as the cutoff date. Cites to our cases were noted in all courts that reported cases and were represented in Shepard's.

5. For a discussion of some of the complexities of the research process, see Cartwright, Conclusions: Disputes and Reported Cases, 9 LAW \& Soc'Y REv. 369 (1975).

6. Goutal, supra note 1. Goutal used standardized pages to correct for different printing styles. The longest French opinion in that time period, according to Goutal, was 1.6 pages, the longest U.S. opinion ran 10.9 pages, and the longest English opinion, 26 pages. Id. at 58.

For additional discussions of cross-national differences in appellate opinions, see J. WETTER, The Styles of APPellate Judicial Opinions (1960); Lawson, Comparative Judicial Slyle, 25 AM. J. CoMP. L. 364 (1977); McWhinney, Judicial Concurrences and Dissents: A Comparative View of Opinion-uriting in Final Appellate Tribunals, 31 GAN. B. REv. 595 (1953); Shapiro, Appeal, 14 LAW \& Soc'y Rev. 629, 651-54 (1980). 
Goutal related these variations in length to differences in legal reasoning. The French style was purely deductive; French opinions simply stated the governing statute or principle, with little reference to the facts of each case or the desirability of the outcome. English opinions, on the other hand, were discursive, reflecting a more inductive approach. English judges carefully compared the facts of the case with those of earlier cases (or hypothetical situations); they reasoned by example and analogy and strove to reach a "reasonable" disposition. The briefer American opinions, Goutal observes, reflected a hybrid style of reasoning: The American judges engaged in some factual exposition, but were (surprisingly, given our English heritage) more like the French, on balance, in that they ultimately tended to deduce the legally "required" answer from a rule extracted from a string of cited cases.

Karl Llewellyn has suggested that the formal, deductive, citationdominated style of American opinions belongs to a specific historical era. ${ }^{8}$ Llewellyn saw in earlier nineteenth-century opinions a more expansive "grand style"; judges such as Marshall and Kent referred to precedents, but tested their outcomes against "principles" and "policy" considerations. ${ }^{9}$

In earlier articles, ${ }^{10}$ we suggested that rapidly growing case loads of later-nineteenth-century court systems may have stimulated a formalistic style, which in turn created pressures to rely heavily on legal rules to decide cases more rapidly, routinely, and efficiently, and to help coordinate the work of lower courts. By the 1930s and 1940s, "legal realism" may have started to affect judicial style. ${ }^{11}$ Llewellyn thought he saw a trend away from formalism in SSG opinions; now a "Style of Reason" was emerging, more concerned with "using sense in the remodeling of doctrine" and paying explicit attention to the social and economic impact of legal doctrine. In this regard, it had a certain kinship to the older "grand style."12 This trend may have

7. Goutal, supra note 1.

8. K. Llewellyn, The Common law Tradition: Deciding Appeals (1960).

9. Id. at 36.

10. Kagan, Cartwright, Friedman \& Wheeler, The Business of Stale Supreme Courts, 1870-1970, 30 STAN. L. REv. 121 (1977) [hereinafter cited as Business of State Supreme Courts]; Kagan, Cartwright, Friedman \& Wheeler, The Evolution of State Supreme Courts, 76 Mich. L. REV. 961 (1978) [hereinafter cited as Evolution of State Supreme Courts].

11. See generally Stevens, Two Cheers for 1870: The American Law School, in 5 PerspecTIVES IN AMERICAN History 405 (D. Fleming \& B. Bailyn eds. 1971); White, From Sociological Jurisprudence to Realism: Jurisprudence and Social Change in Early Twentieth-Century America, 58 VA. L. REV. 999 (1972).

12. K. LlewellyN, supra note 8 , at $51,140-41$. 
both contributed to and reflected reforms in judicial structure that gave SSCs discretion to accept only a smaller number of more "important" cases. ${ }^{13}$

As we noted, Goutal found American SSC opinions neither so short as French opinions nor so long as those of British high courts. Averages, of course, can be misleading. It seems reasonable to assume that judges write shorter opinions, in the main, for cases they perceive to be "easy"-clearly controlled by legal precedent-and longer ones in cases they feel are legally difficult, or politically controversial, or liable to have major social impact. ${ }^{14}$ Many American SSC decisions are much like French opinions; they are set forth in per curiam judgments less than a page in length, supported by no "reasoning" other than stark citations to a few prior cases, if that. ${ }^{15}$ At the other end of the spectrum, a small proportion of American SSC opinions are quite lengthy. In our sample of 5,900, we found 56 majority opinions that went on for 20 pages or more. ${ }^{16}$ (All references to page length are to a "standard page," used to correct for variations from state to state and over time in the density of print in the official reporters. We chose a moderately dense, 2,800-character page as our standard.) But what is the trend over time? Has the average SSC opinion gravitated toward the cryptic French model or toward the discursive British one?

For several reasons, one might expect SSC opinions to have grown longer, on average, over the 1870-1970 period. A primary reason is that each state has more of its own law to cite and discuss with each passing year of new decisions. A second reason is that the proportion of "important" cases decided by SSCs has probably in-

13. See Evolution of State Supreme Courts, supra note 10, at 997-1001.

14. See B. Cardozo, The Nature of the Judicial Process 164 (1921) ("Of the cases that come before the court in which I sit, a majority, I think, could not, with semblance of reason, be decided in any way but one. The law and its application alike are plain. Such cases are predestined, so to speak, to affirmance without opinion." [That is, via memorandum opinion.]).

15. Llewellyn noted that of the $137 \mathrm{New}$ York Court of Appeals cases in volume 155 of West's Northeastem Reporter (1927), 88 (64\%) were memoranda noting an affirmance without opinion. K. LlewEllyN, supra note 8, at 25 n.16.

16. When we count concurring and dissenting opinions as well, 88 cases (1.5\%) covered 20 or more pages.

Page length was calculated as follows. We multipled the number of pages of each opinion in the official state reports by the average number of characters per page for that statetime sampling point. We then divided this estimate of total characters per opinion by the national average of characters per page $(2,782.1)$ to create a standardized page length, consistent for all jurisdictions and time periods. We note that the standard page used by Goutal was 4,000 characters. Goutal, supra note 1, at $57 \mathrm{n} .45$. This is closer to the smaller type used in West's reporters, which contained at least 4,300 characters per page for most of the period of our study. 
creased. ${ }^{17}$ Social change has accelerated, together with more intense demands for equality and due process, and the continuing struggle of groups for control of the levers of the economy. Goutal, for example, observed that the English appellate opinions in contract cases had grown longer only in the twentieth century, as judges labored to adapt earlier precedents to changed political and economic conditions. ${ }^{18}$ Then too, there have been changes in court structure: As SSC judges gain more control over their own dockets, they will presumably choose to hear a higher proportion of hard cases, which might lead to longer opinions. Finally, even if the mix of "easy" and "hard" SSC cases has not changed significantly, changes in legal philosophy-the decline in the belief in a "single right answer," the rise of emphasis on "reasoned elaboration" of decisions, ${ }^{19}$ and attention to social and political context-may have impelled judges to provide longer, more policy-oriented justifications for their positions.

A competing hypothesis, however, might suggest that most SSC opinions should have become shorter over time. With rising population, the demand for appellate review increases steadily. ${ }^{20}$ The Michigan Supreme Court issued an average of 499 opinions a year in the 1900-1910 period. In 1971, 3,238 petitions for review were filed in the California Supreme Court, 1,069 in New Jersey, and 959 in Louisiana. ${ }^{21}$ Mounting case loads presumably leave SSC judges less time to deal with each case, even though they have had clerks to help them for the last generation or so. ${ }^{22}$ Goutal, for example, referred to case-load pressures in explaining the failure of American SSC cases to expand nearly as much as the leisurely reasoned British opinions in the twentieth century. ${ }^{23}$ Consequently, except for a small propor-

17. Peter Harris has shown that between 1870 and 1970 , the number of SSC cases with multiple litigants and with amicus briefs increased, along with other indicators of "importance," such as percentage of nonunanimous decisions. P. Harris, The Communication of Precedent Among State Supreme Courts, ch. 4 (Dec. 1980) (unpublished dissertation presented to and accepted by faculty of graduate school of Yale University).

18. Goutal, supra note 1 , at 61-64.

19. See White, The Evolution of Reasoned Elaboration: Jurisprudential Criticism and Social Change, 59 VA. L. REV. 279 (1973).

20. See Evolution of State Supreme Courts, supra note 10.

21. Clark, American Supreme Court Caseloads: A Preliminary Inquiry, 26 AM. J. COMP. L. 217 (Supp. 1978).

22. For discussions of case-load pressures in the U.S. Supreme Court, see FEDERAL JUdicial Center, Report of the Study Group on the Case Load of the Supreme Court (1972) (The Freund Report); Casper \& Posner, A Study of the Supreme Court's Caseload, 3 J. LeGal Stud. 339 (1974); Griswold, Rationing Justice-The Supreme Court's Caseload and What the Court Does Not Do, 60 Cornell L. Rev. 335 (1975); Hart, Foreword: The Time Chart of the Justices, 73 HARV. L. REV. 84 (1959).

23. Goutal, supra note 1, at 65-69. Goutal found that American opinions in third-party- 
tion of especially difficult or controversial cases, one might expect judges on modern, busy SSCs to write shorter opinions than their nineteenth-century predecessors.

With our data, we cannot evaluate these hypotheses definitively. We were able to measure the length of published opinions only, and hence were forced to bypass the unpublished opinions that some busy SSCs have resorted to at various points over the last century. In addition, we deliberately excluded from our study published SSC opinions shorter than one full page because we wished to focus on those cases the SSCs themselves regarded as of some significance; we omitted numerous per curiam or memorandum opinions, as well as other short opinions (usually dealing with jurisdictional issues). Because of these choices, we cut off the "very short" end of the distribution of SSC opinions.

\section{A. National Trends in Opinion Length}

Table 1 sets forth the average number of (standardized) pages in the majority opinions of the 16 SSCs in seven time periods. The average opinion increased from four pages in 1870-1880 to about six pages in the $1945-1970$ period. Is this a big or a small increase? That depends: A critic of judicial wordiness, decrying the inflation of opinions, could point out that modern decisions were $50 \%$ longer than those a century ago. Defenders of the courts could call the increase small: a mere two pages of "inflation." The average SSC opinion, after World War II, was still less than half the length of Goutal's English contract cases. ${ }^{24}$ In either case, however, the hypothesis that opinions would grow longer has been confirmed, and the hypothesis that judges would become too busy to write longer opinions is disconfirmed (except for the possibility, to be discussed later on, that case-load pressures kept opinions from growing even longer).

Was the growth of opinion length, however, merely the product of longer opinions in more difficult or "important" cases, or did "easy" opinions grow longer as well? We have no objective measure, of course, of difficulty or importance. The best we could do was

beneficiary contract cases averaged 2.7 pages in the 1861-1914 period, compared with 3.5 pages for English cases. But in the 1915-1944 period, while U.S. cases grew only slightly to 2.9 pages, the English cases soared to 12.6 pages. Id. at 58 (table).

24. Converting Goutal's 4,000-character "standard page" to our 2,800 word "standard page," the average British third-party-beneficiary contract case in the post-World-War-II periods was over 14 pages. Id. The average SSC contract case (we did not code third-partybeneficiary cases separately) in the $1950-1970$ period was 6.6 pages. 
count the number of times each case in our sample was cited in subsequent appellate court opinions, both in the home state and outside. Some opinions, to be sure, are cited because they contain a nice aphorism or a concise restatement of a legal principle, rather than because the case is intrinsically important. Still, it is likely that, on balance, cases in our sample that were cited more than 12 times each in subsequent opinions were more important than opinions that were never cited, or cited only once, in subsequent cases. Table 1 shows mean page length for each of these two classes of cases. Subsequently cited opinions are consistently about twice as long, on the average, as opinions cited by one or fewer subsequent cases. Also, the subsequently cited opinions expanded substantially over time, from an average of 5.4 standardized pages in $1870-1880$ to 9.5 pages in 1960-1970, an increase of more than four pages. However, their rate of growth (76\%) was almost matched by the growth $(61 \%)$ of the ostensibly "routine" opinions that were ignored by judges in subsequent cases. ${ }^{25}$

\section{TABLE 1}

Length of SSC Majority Opinions

$\begin{array}{cccccccc}1870- & 1885- & 1900- & 1915- & 1930- & 1945- & 1960- & \text { All } \\ 1880 & 1895 & 1910 & 1925 & 1940 & 1955 & 1970 & \text { Periods } \\ 3.99 & 4.37 & 4.46 & 4.73 & 4.99 & 5.97 & 6.02 & 4.96 \\ & & & & & & & \\ 3.1 & 3.0 & 3.0 & 3.4 & 3.7 & 4.0 & 5.0 & 3.8\end{array}$

2. Mean Number of
Pages, Majority Opinions Cited in One or Fewer Subsequent Cases (21.7\% of all SSC cases)

1. Mean Number of Pages, Majority Opinions

3. Mean Number of Pages, Majority Opinions Cited in More Than 12 Subsequent Cases $(23.2 \%$ of all SSC cases)

4. Percentage of Majority Opinions 10 Pages or Longer

5. Mean Number of Pages, Dissenting Opinions

$\begin{array}{llllllll}5.4 & 5.8 & 6.1 & 6.4 & 7.4 & 8.7 & 9.5 & 6.6\end{array}$

$\begin{array}{llllllll}5.7 & 6.5 & 4.9 & 6.4 & 7.5 & 12.2 & 11.3 & 7.8\end{array}$

25. Dissenting and concurring opinions, on the average, have been only half as long as 


\section{B. Interstate Variation in Opinion Length}

As noted earlier, Jean Goutal has argued that American appellate opinions did not grow as much as English ones over the 1860-1940 period because American courts had to write so many opinions. In fact, that was true of only some SSCs, as Table 2 shows. Some SSCs averaged over 300 , and sometimes over 400 , opinions a year. But throughout the 1870-1970 period, about half the SSCs issued fewer than 175 opinions a year. Furthermore, overall statistical correlation between opinion volume and opinion length, while consistently in the expected direction, is not uniformly powerful. In $1870-1880$, it was -.38; in 1900-1910, -.58; in 1930-1940, only -.08; and in $1960-1970,-.17$. The relationships are about the same or slightly higher when we correlate average opinions per judge with average opinion length. ${ }^{26}$

Most of the SSCs with low opinion loads were in states with small populations_-Idaho, Maine, Nevada, Rhode Island, and South Dakota. These SSCs averaged less than 150 opinions a year, and usually had less than 100. Thus these states did not need to establish a tier of intermediate appellate courts (IACs) between trial courts and the SSC. In contrast, in states whose populations grew to over $1,000,000$, and in which appeal to the SSC remained available as of right, SSC opinion loads often soared to over 300 a year. In some of these states, such as Minnesota, no IAC was established. In Michigan and North Carolina, IACs were created, but not until the mid1960s. Illinois and Alabama established IACs in the late nineteenth and early twentieth century, but litigants could still bypass the IAC and appeal directly to the SSC as of right in a substantial proportion of cases.

The medium-sized and larger states which did establish effective ways of controlling SSC opinion loads are marked with an asterisk in Table 2. By 1870, New Jersey already had an IAG system that screened out most appeals; in 1948 its SSC gained almost complete discretion to select cases. West Virginia had no IAC, but its SSC had discretion to reject "unmeritorious" appeals. Tennessee established

majority opinions; but they have grown rapidly in recent years, from an average of about two pages (1950) to an average of $3.2(1960-1970)$.

26. In 1870-1880, the correlation of opinions per judge and page length was -.42; in $1900-1910,-.56$; in 1930-1940, -.09; and 1960-1970, -.39. 


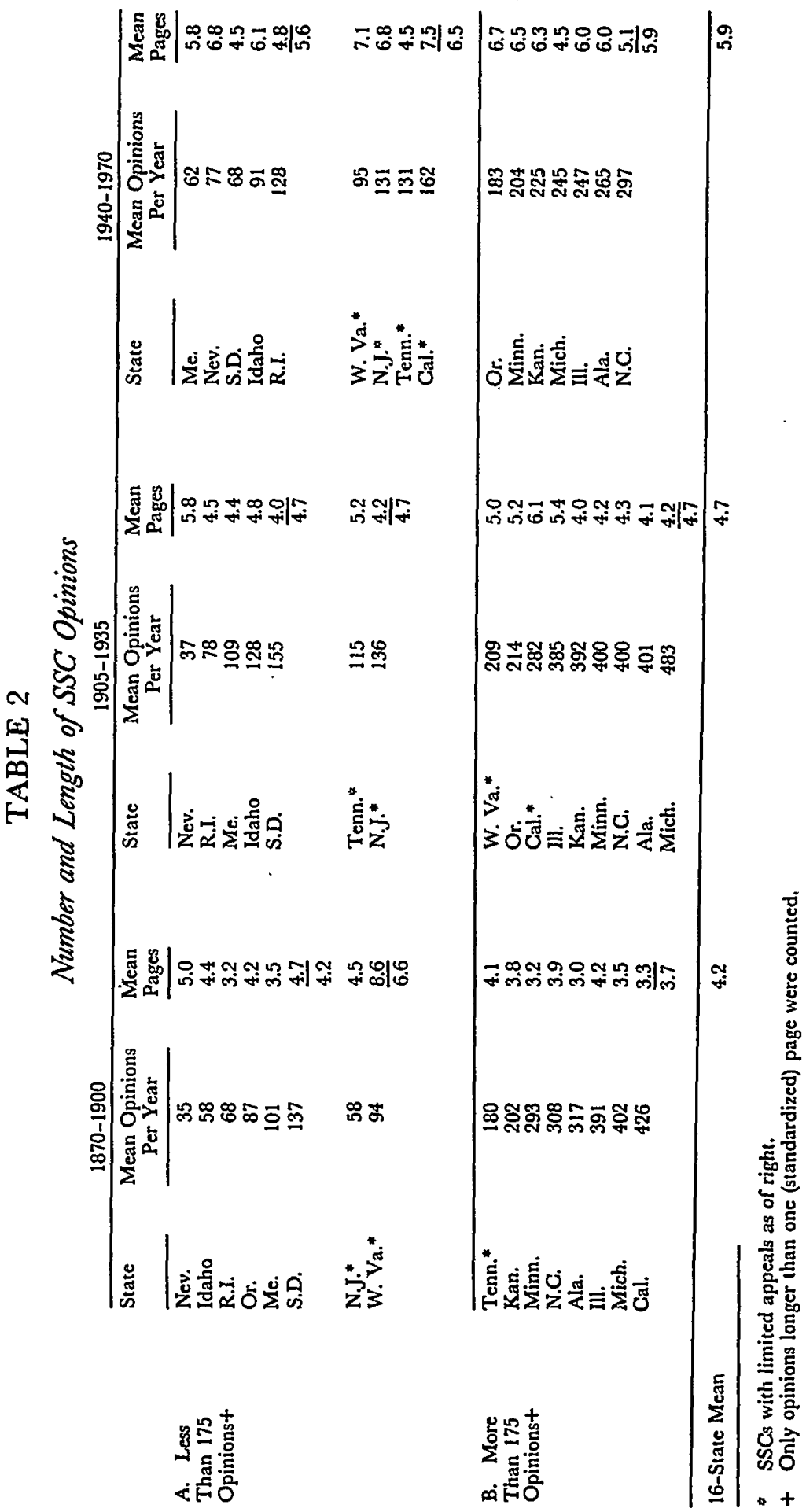


an IAC for some types of cases in the 1890s. California established an IAC in 1904, and its SSC began to exercise almost complete caseselecting discretion in the post-World-War-II era. ${ }^{27}$ These SSCs with more discretion usually issued less than 175 opinions a year.

This variation in SSC structure helps us to examine more carefully the relationship between opinion volume and length. Consider first the small-state SSCs. In the 1870-1900 period, they averaged slightly longer opinions (4.2 pages) than the large opinion-load states (3.7 pages), suggesting that case load does constrain opinion length. But from 1870-1900 to the 1905-1935 period, opinions grew only slightly in the small states, even though these states enjoyed relatively low case loads, and grew no more than did the larger states' opinions, despite the phenomenal case loads of the latter. And by 1940-1970, as case loads fell off slightly in the large opinion-load SSCs, courts averaging more than 175 opinions a year wrote slightly longer opinions (5.9 pages on average) than the small-state SSCs, which generally wrote fewer than 100 opinions (averaging 5.6 pages).

There are also very wide differences in opinion length within groups of courts with similar case loads. In 1940-1970, for example, the Nevada Supreme Court, which issued an average of 77 opinions a year, wrote opinions that averaged 6.8 pages; the average opinion of the South Dakota Supreme Court, which had a slightly smaller case load, was only 4.5 pages long.

At first blush, therefore, there is a correlation between opinion length and case load, but only a moderate one. A more detailed look at the data, however, suggests a stronger relationship, particularly when a SSC has discretion in selecting cases (and hence is able to concentrate on cases it considers "important"). Here are some revealing items:

(1) In 1870-1900, the California Supreme Court averaged the most opinions per year (426), and almost the shortest opinions (3.3 pages). In 1905-1935, with an IAC buffer and some discretion, it cut its production of opinions to an average of 282 a year, and wrote the longest opinions (6.1 pages). In 1940-1970, exercising almost total discretion over its docket, it averaged 162 opinions, and again wrote the longest opinions (7.5 pages).

(2) In 1965, the North Carolina Supreme Court wrote 475 opinions. In 1970, after getting control of its docket, it wrote 118.

27. For more details on court structure and jurisdictional rules, as well as on the dynamics of change, see our Evolution of Stale Supreme Courts, supra note 10. 
Average length grew from five pages to eight pages. ${ }^{28}$

(3) In 1870-1900, the West Virginia Supreme Court, which had the most extensive discretion of the 16 SSCs at that time, wrote opinions that averaged 8.6 pages, more than twice the mean for the 16 states. But in 1905-1935, as its case load expanded from an average of less than 100 to over 200 per year, its opinions declined in length (to an average of five pages). In 1940-1970, when it again reduced its opinion load (to less than 100 a year), the West Virginia court became one of the wordiest, averaging 7.1 pages per opinion (exceeded only by the 7.5 pages of California, another high-discretion SSC, and, in the 1960-1970 period, by the high-discretion New Jersey Supreme Court ${ }^{29}$ ).

(4) In 1945-1955, the Nevada Supreme Court averaged only 36 opinions a year, and the Oregon Supreme Court averaged 115. The opinions of both averaged about nine pages, $50 \%$ longer than the 16-state mean of six pages. In 1960-1970, however, the Nevada Supreme Court's opinion load spurted to an average of 131 (218 in 1970), and its opinion length dropped to 4.6 pages. The Oregon Supreme Court case load soared to an average of 274 in 1960-1970, and its average opinion shrank to only 4.2 pages, well below the six-page mean for the 16 SSCs.

Nevertheless, case load hardly "explains" opinion length. The traditions and role-conceptions of SSC judges are also important. How else could one explain the West Virginia Supreme Court's 9.2 page average in 1870-1880, when most other SSCs averaged about 3.5? SSG opinions in the small New England states of Rhode Island and Maine were consistently shorter than those of the Nevada and Idaho SSCs, which had similar case loads. New Jersey's Court of Errors and Appeals averaged 136 opinions per year in 1905-1935 and wrote shorter-than-average opinions. When transformed into the New Jersey Supreme Court in 1948, given more case-selecting discretion, and provided with strong leadership by Chief Justices Vanderbilt and Weintraub, it issued no fewer opinions, but its average opinion in 1940-1970 was 6.8 pages, almost a full page longer than the mean for the 16 states. Moreover, in 1960-1970, its opinions averaged 10.2 pages, compared to a mean for the 16 states of 6.6 pages; California was in second place with 9.7. This suggests that the ex-

28. For more detail on North Carolina, see Groot, The Effects of an Intermediate Court on the Supreme Court Work Product: The North Carolina Experience, 7 WAKE FOREST L. REv. 548 (1971).

29. The mean opinion page-lengths for 1960-1970 were New Jersey, 10.2; California, 9.7; West Virginia, 8.0; Idaho, 7.5; Minnesota, 7.4; Maine, 6.9; Alabama, 6.6; Michigan, 6.4; Kansas, 6.2; North Carolina, 5.9; Illinois, 5.8; South Dakota, 5.4; Rhode Island, 4.9; Tennessee, 4.9; Nevada, 4.7; Oregon, 4.5. The overall mean was 6.6 pages. 
plicitly "policy-making" posture adopted by "legal realist" judges, as we find in New Jersey and California, leads to longer opinions; but to explain all the ins and outs of the data would require close study of the judicial culture of particular courts, along with the details of court jurisdiction, work load, and opinion-writing practices.

\section{Dissent Rates in State Supreme Courts}

In many civil law systems, judges do not sign opinions, and all reported decisions are unanimous. ${ }^{30}$ The common law tradition is very different. In English appellate decisions, there is often a series of opinions. Each judge writes his own opinion, even if he concurs in the result; and of course, the judge may also dissent. Before John Marshall took over as Chief Justice in 1801, U.S. Supreme Court Justices also wrote seriatim opinions. ${ }^{31}$ Under Marshall, the practice ended. To Marshall, as to many judges, a unanimous opinion carried more weight than one that trailed with it concurrences or dissents. Separate opinions tend to sap the legitimacy of a court. Such opinions suggest that decisions are the product of each judge's personal predilection, rather than ineluctable deduction from "the law."

Even on well-established courts, judges who believe in a strict line between law and policy, and who think that courts should faithfully follow precedent, have criticized the practice of writing dissenting opinions. Dissents, they argue, undercut the law's predictability; they raise hopes that the view of today's dissenters might become tomorrow's law. One legal scholar called dissents "a menace to law and order"; a judge who disagrees with his fellow judges should keep his views inside the conference room, so that the court may appear "as a united family" to the world. ${ }^{32}$

Dissents do sometimes reveal broad differences in philosophy, or expose differing tastes or idiosyncracies among judges; they do explode the myth that legal questions have a single right answer. Stylistically, dissents tend to be looser and more flamboyant than majority opinions. ${ }^{33}$ Some courts have had particularly cranky or

30. Shapiro, supra note 6 , at 653 .

31. See generally R. Newmyer, The Supreme Court Under Marshall and TANey (1968).

32. Lee, Dissenting Opinions, 2 John Marshall L.Q. 404, 405-06 (1937). See also Hirt, In the Maller of Dissents Inter Judices de Jure, 31 PA. B. Ass'N Q. 256 (1960). For a more positive view, see Fuld, The Voices of Dissent, 62 CoLuM. L. REV. 923 (1962).

33. See, e.g. , McCreight, Some Dissenting Opinions, 31 ANN. REP. PA. B. Ass'N 331, 337-45 (1925). They may differ in citation patterns, but we did not record citation data for dissents. We did record dissent length. See Table 1. 
colorful dissenters. Justice Meriot Glarkson, who sat in North Carolina in the 1930s, was such a judge. In Ingle v. Cassady, an auto accident case, Clarkson thought there was enough evidence of negligence for the case to go to the jury; the majority did not. ${ }^{34}$ Clarkson's dissent ended with a blast at the majority: "It is a matter of grave concern to those who travel on the highways of the state to take away from the jury the rule of the prudent man, even in an emergency. This court would soon become an autocracy of five, and trial by jury a misnomer. The American authorities are, I might say, almost unanimous against the position taken in the main opinion."35

Dissents such as these ruffle feathers; and they lend color to arguments that dissents display unseemly wrangling, and harm the image of courts. Still, any views about the undesirability of dissent fall on deaf ears as far as the contemporary U.S. Supreme Court is concerned. Dissent was rare in John Marshall's day; unanimity is rare today. Only about a quarter of the Court's reported opinions are unanimous. ${ }^{36}$ In many controversial cases, we find four or five concurring and dissenting opinions. In Furman v. Georgia, the death penalty case, all nine justices wrote opinions. ${ }^{37}$

\section{A. National Trends in Dissent Rates}

Such extremes, however, are rare in SSGs. Unanimous opinions

34. 208 N.C. 497,181 N.E. 562 (1935). Miss Cassady, the defendant, drove her Plymouth to the Chicago World's Fair, taking along three passengers, including the plaintiff, to share gas and other expenses. While Miss Cassady was driving, the car began to shimmy and shake; eventually it went off the road. The plaintiff was injured and sued Miss Cassady. The trial court threw the case out, the supreme court affirmed.

35. Id. at 501, 181 N.E. at 564 (Clarkson, J., dissenting). His dissent in Newman v. Commissioners of Vance County, 208 N.C. 675, 182 N.E. 453 (1935), was even more personal in tone. The legislature passed a law letting the voters of Vance County decide if they wanted the county to be legally wet. (The state, in general, was dry.) The court upheld the statute. Clarkson, a passionate dry, dissented in an opinion that ran on for about 17 printed pages. The climax was a marvelous burst of invective: "No person, family, community, county, state or nation" could ever "reach the height of health, happiness, and prosperity" if "addicted" to drink. Liquor was worse than "war, pestilence, and famine"; it was "an evil that must be destroyed, a habit-forming drug like opium and other narcotics." The statute under attack was "jungle, crazy-quilt legislation, and a blot on the garment of this great commonwealth." Id. at 694-95, 182 N.E. at 465-66 (Clarkson, J., dissenting).

36. See Halpern \& Vines, Institutional Disunity, the Judges' Bill and the Role of the U.S. Supreme Court, 30 W. POL. Q. 471 (1977); Zobell, Division of Opinion in the Supreme Court: A History of Judicial Disintegration, 44 CORNELL L.Q. 186 (1959). Justice William O. Douglas went so far as to say: "The right to dissent is the only thing that makes life tolerable for a judge of an appellate court." W. Douglas, America Challenged 4 (1960). See also Douglas, The Dissent: Safeguard of Democracy, 32 J. AM. JuD. Soc'y 104, 107 (1948).

37. 408 U.S. 238 (1972). It was an achievement when Chief Justice Warren was able to gain unanimity in Brown v. Board of Education, 347 U.S. 483 (1954). 
have been, and remain, overwhelmingly dominant. The national trend, using our $16 \mathrm{SSCs}$ as a national sample, is shown in Table 3. We excluded from our sample opinions less than a page in length, which are almost always unanimous; our figures thus overstate dissent rates somewhat. In the late nineteenth century (aggregating the 1870-1900 data), $91.3 \%$ of the published opinions were unanimous. There were concurring opinions in $2.7 \%$ of the cases, and dissents in $6.0 \%$. In the twentieth century, the dissent rate gradually crept upward, from $6.4 \%$ in $1900-1910$, to $10.2 \%$ in $1930-1940$, and to $12.8 \%$ in 1960-1970, double the rate of a century earlier. Still, even in 1960-1970, 83.5\% of SSC opinions were unanimous. SSGs appear still to conform more or less to the ideal of the "united family."

\section{TABLE 3}

\section{National Trends in Unanimity}

\begin{tabular}{|c|c|c|c|c|c|c|c|}
\hline & $\begin{array}{l}1870- \\
1880 \\
\end{array}$ & $\begin{array}{l}1885- \\
1895 \\
\end{array}$ & $\begin{array}{l}1900- \\
1910 \\
\end{array}$ & $\begin{array}{l}1915- \\
1925 \\
\end{array}$ & $\begin{array}{l}1930- \\
1940 \\
\end{array}$ & $\begin{array}{l}1945- \\
1955 \\
\end{array}$ & $\begin{array}{l}1960- \\
1970 \\
\end{array}$ \\
\hline $\begin{array}{l}\text { Percent SSC } \\
\text { Opinions }\end{array}$ & & & & & & & \\
\hline Unanimous $\ldots \ldots \ldots \ldots \ldots$ & 91.4 & 90.8 & 92.5 & 88.9 & 86.9 & 86.3 & 83.5 \\
\hline $\begin{array}{l}\text { With } \\
\text { Concurrences............ }\end{array}$ & 2.6 & 3.3 & 1.2 & 2.2 & 2.9 & 3.2 & 3.7 \\
\hline $\begin{array}{l}\text { With } \\
\text { Dissents } \ldots \ldots \ldots \ldots \ldots \ldots\end{array}$ & 6.0 & 5.9 & 6.4 & 8.9 & 10.2 & 10.4 & 12.8 \\
\hline
\end{tabular}

This moderate increase in dissent, viewing all SSCs as a group, masks some sharper variations. For instance, dissent rates, our data indicate, are higher for more "important" cases. As we suggested earlier, opinions that are frequently cited in subsequent appellate court cases are probably more important in developing legal doctrine, on average, than cases that have little or no impact as precedent. We have already seen that SSCs wrote longer opinions in such cases. $^{38}$ Table 4 shows that $15.6 \%$ of such "important" cases had dissenting or concurring opinions, over the whole 100-year span, compared with $11.5 \%$ of "all cases" and $9.0 \%$ of cases without any significance as precedents. ${ }^{39}$ In the $1940-1970$ period, dissenting or concurring opinions appeared in more than one of every four (28.7\%) SSC opinions that received substantial attention in later cases. Fur-

38. See Table 1; text accompanying note 25 supra.

39. Of course, it is possible that the presence of a dissenting or concurring opinion contributes to the likelihood that an opinion will be cited subsequently. The fact remains, how- 
thermore, this rate is more than double the "dissensus" rate for "important" decisions in 1905-1935, suggesting that "SSC judges, like their U.S. Supreme Court counterparts, are increasingly willing to dissent in important cases. As more SSCs gain discretion to select only "important" cases-a prerogative only three of our SSCis enjoyed in large measure throughout the 1940-1970 period-one might expect the overall dissensus rate to approach $25 \%$.

\section{TABLE 4}

\section{National Trends in Unanimity of Opinions in "Important" and "Unimportant" Cases}

\begin{tabular}{|c|c|c|c|c|}
\hline $\begin{array}{c}\text { Percent } \\
\text { Nonunanimous } \\
\end{array}$ & $1870-1900$ & 1905-1935 & $1940-1970$ & All Periods \\
\hline All Opinions $\ldots \ldots \ldots \ldots \ldots$ & 8.7 & 10.5 & 15.0 & 11.5 \\
\hline $\begin{array}{l}\text { Opinions Cited in More than } \\
12 \text { Later Cases ............ }\end{array}$ & 10.6 & 13.3 & 28.7 & 15.6 \\
\hline $\begin{array}{l}\text { Opinions Cited Once or Never } \\
\text { in Later Cases.............. }\end{array}$ & 6.6 & 8.7 & 10.2 & 9.0 \\
\hline
\end{tabular}

\section{B. Interstate Variation in Dissensus}

The notion that case-selecting discretion is associated with higher dissent rates receives support from a study by Bradley C. Canon and Dean Jaros. ${ }^{40}$ They hypothesized that both organizational factors, such as lower case loads and IACs, and essentially cultural factors, such as judicial attitudes, affect SSC dissent rates. As a proxy for the cultural factors, Canon and Jaros measured the social and political diversity of the state in which the SSC sits. Using a sample of 7,880 cases from all 50 SSCs during 1961-1967, they found that the IACs were the most important determinant of an SSC's dissent rate, far overshadowing such factors as the size of the state, its degree of urbanization, its economic characteristics, its method of judicial selection, and interparty competitiveness in the state's elections. When an IAG was present, presumably screening out more routine cases and reducing the SSC's case load, dissent rates were higher; and only in IAC-buffered SSCs did heterogeneity in the state's population and political makeup contribute to a higher dissent rate.

ever, that over $80 \%$ of $\mathrm{SSC}$ opinions cited in more than 12 subsequent cases were unanimous. This suggests that some cases are "intrinsically" more "important" than others, regardless of whether all the judges agree on the outcome.

40. Canon \& Jaros, External Variables, Institutional Structure and Dissent on Slate Supreme Courts, 3 POLITY 175 (1970). 
Our data add historical perspective to the Canon and Jaros findings. Looking at SSCs over time, for example, leads us to draw a distinction between the presence of an IAC system (which Canon and Jaros emphasized) and a jurisdictional grant of case-selecting discretion. Some states, such as Illinois and Alabama, established IACs in the late nineteenth or early twentieth century. But, as mentioned earlier, these were "weak" IAG systems that did not allow the SSC to substantially control its own case load. West Virginia's SSC had no IAC buffer, but did have case-selecting discretion. To reflect such jurisdictional differences, Table 5 arranges our 16 SSCs in three groups: (1) small case-load SSCs in small states, without substantial case-selecting discretion; (2) large case-load SSCs in medium- and large-sized states, none of which had "strong" case-selecting discretion before 1965; and (3) SSCs in medium- or large-sized states, with strong IAC buffers or case-selecting discretion. ${ }^{41}$

In the 1945-1970 period, the SSCs with the most case-selecting discretion-California, New Jersey, and West Virginia-experienced a much higher incidence of nonunanimous opinions than the average SSC. Almost half of the New Jersey Supreme Court's opinions in the 1945-1955 sample had concurring or dissenting opinions; $38.9 \%$ of California's opinions in the 1960-1970 sample were divided. The only other SSC in our sample with a similar record of divisiveness is Michigan, where $44.4 \%$ of cases in the $1960-1970$ period had a concurring or dissenting opinion. Michigan established an IAC and granted its SSC case-selecting discretion in 1964.

More impressive than the relationship between discretion and dissent, however, is the enormous variation in dissent rates between SSCs with comparable court structures. Clearly, a low case loadwhich might give the judges more time for opinion writing (or hairsplitting) -does not necessarily produce a higher rate of dissents or concurrences. Some small-volume courts, such as Maine and Rhode Island, have a consistent tradition of consensus, ${ }^{42}$ while others, such as Nevada in the late nineteenth century and Idaho since 1915, have dissent rates far above average. The Tennessee Supreme Court's case load was consistently well below average, but it also had a tradition of near unanimity. California, in the late nineteenth century, had a

41. California is placed in the third group, although it did not have an IAC system until 1905 and, like New Jersey, did not exercise "strong" case-selecting powers until the 1945-1970 period. Tennessee, placed in the third group, had an IAC and low opinion-loads, but had less case-selecting discretion.

42. See Beiser, The Rhode Island Supreme Court: A Well-Integrated Political System, 8 LAw \& SOC. REV. 167 (1973). 

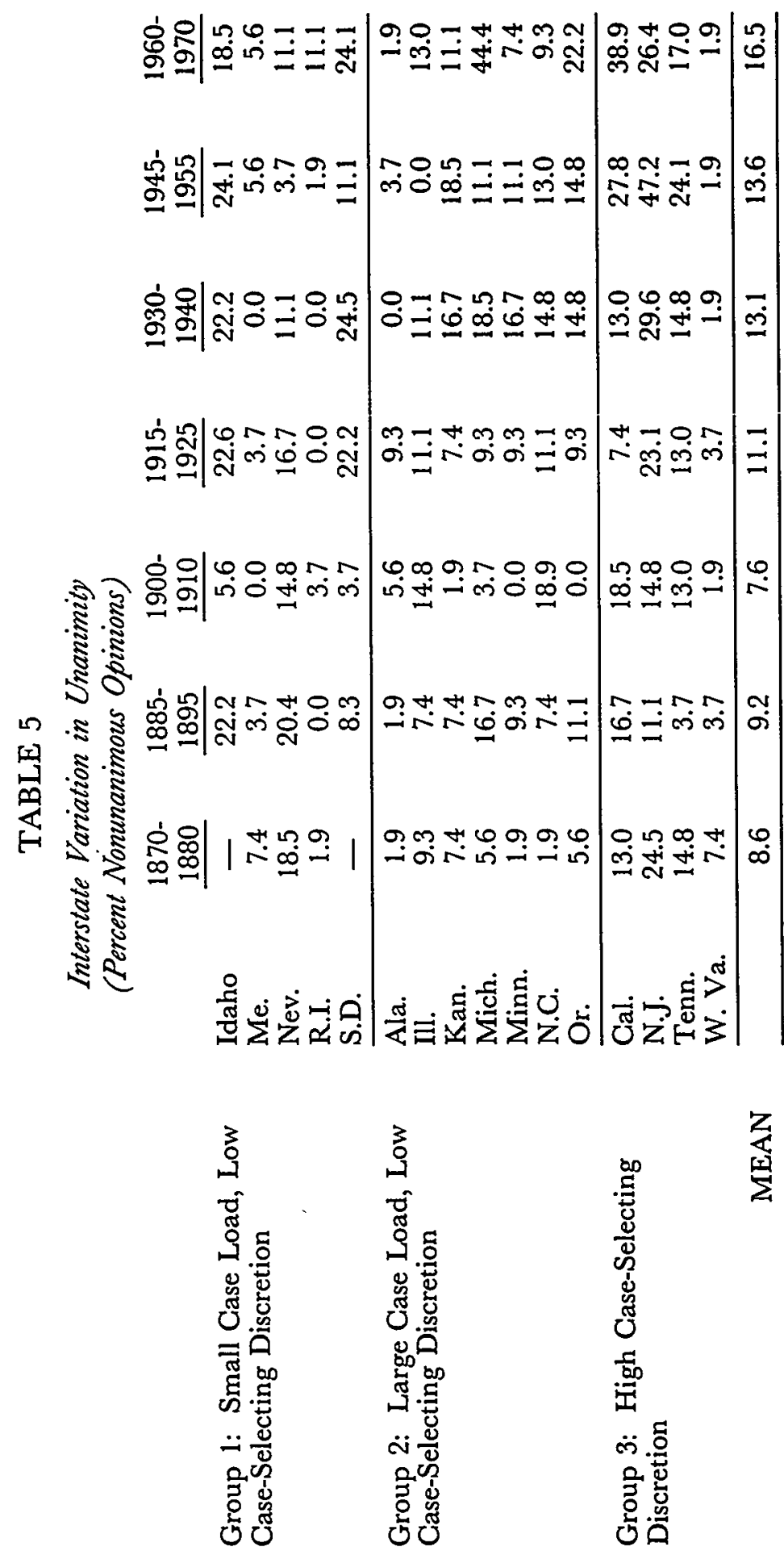
high dissent rate despite low discretion and a massive case load (the largest in our sample). Larger industrialized states did not necessarily generate a high proportion of controversial, dissent-provoking SSC cases; California and New Jersey were higher than average in most time periods, but Michigan and Illinois were apt to be below average.

These variations suggest that more subtle intracourt cultural factors were powerfully at work, as do the striking variations in dissent rates within the same SSG over time. Surely only the internal opinion-writing norms of a particular panel of judges ${ }^{43}$-or the specific policies of a strong chief justice-could explain why the Illinois Supreme Court had no concurrences or dissents in the 54 cases we sampled in the 1945-1955 period. There were sharp dips in the dissent rate in the SSCs of Minnesota in 1900-1910, Oregon in 1900-1910, and California in 1915-1925. Only changes in intracourt norms, it would seem, or changes in personnel that produced a clash between politically or philosophically divided blocs of judges, could explain why the South Dakota Supreme Court's dissent rate, very low in the 1885-1910 period, jumped to over 20\% in the 1915-1940 period. (Its case load was about the same in the two periods.) Moreover, its dissent rate in recent years has approached $25 \%$, about twice as high as the SSC in neighboring North Dakota, a state with a similar economy and population. ${ }^{44}$

In The Common Law Tradition: Deciding Appeals, Llewellyn asked whether a judicial style more open to policy considerations, influenced by legal realism, might "kill court teamwork." He noted that in 1939 dissents were written in only one-tenth of the Ohio Supreme Court's decisions. In 1959, after that court moved toward what Llewellyn called a nonformalistic "Style of Reason," fully one-quarter of the court's opinions provoked dissents. ${ }^{45}$ The New York Court of Appeals rarely had dissenting opinions before Benjamin Cardozo joined the court. Cardozo, according to Llewellyn, professed a "Style of Reason"; within a few years, dissenting opinions appeared in one of every seven cases. ${ }^{46}$ Our data support Llewellyn's view. Of our 16 SSCs, those with the highest rates of divided opinions in the

43. See, e.g., Sickels, The Illusion of Judicial Consensus: Zoning Decisions in the Maryland Court of Appeals, 59 Am. Pol. Sci. Rev. 100 (1965). See generally R. Leflar, InTERnal Operating Procedures of APpellate Courts (1976).

44. Cann, Social Backgrounds and Dissenting Behavior on the North Dakota Supreme Court, 1965-1971, 50 N.D.L. REV. 773, 778 (1974).

45. K. LlEWELLYN, supra note 8 , at 462 .

46. Id. at 463 . 
1945-1970 period were the New Jersey and California Supreme Courts, both of which built reputations during this period as innovative law reformers. ${ }^{47}$ The Michigan Supreme Court, which split in almost half of its sampled cases in the 1960-1970 period, was racked by conflict between liberal and conservative voting blocs; each bloc castigated the policies and politics of the other. ${ }^{48}$

But Llewellyn also pointed to at least one countervailing example. He took a sample of 50 North Carolina Supreme Court opinions from 1940 and found them moving from the formal style to the "Style of Reason"; 24\% involved dissenting or concurring opinions, many of which had a "nasty tone." Yet since then, Llewellyn wrote in 1960, "[t]he Style of Reason has flourished . . . in North Carolina," but dissents decreased and those that remained lacked the nasty tone. ${ }^{49}$ In 1970 , some of the Rhode Island Supreme Court's five justices, according to Edward Beiser's interviews, were politically conservative "strict constructionists"; others applauded the Warren Court's boldness and believed that courts should be "responsive to the times." 50 Yet concurring and dissenting opinions were below our 16-state average. The North Carolina and Rhode Island examples suggest, once again, that many factors affect dissent rates; a tradition of collegial interaction or judicial leadership can sometimes dampen whatever tendencies toward dissensus emerge from a more freewheeling judicial philosophy. ${ }^{51}$

\section{Gitation Patterns of State Supreme Courts}

In this section, we look at the "authority of authority"52 — citation patterns of SSCs. A "citation" in a judicial opinion refers to "authority"- a case, statute, treatise, or article. Most cases, though by no means all, cite authority. How have our 16 SSCs behaved over the course of the century, 1870-1970?

Before we proceed, it is worthwhile to ask why judges cite author-

47. On the New Jersey Supreme Court, see Glick \& Vines, Law Making in the State Judiciary: A Comparative Study of the Judicial Role in Four States, 2 PoLrTY 142 (1969). On California, see the portrait of Justice Roger Traynor in G. E. WhITE, ThE AMERICAN Judicial TRadiTION 292 (1976).

48. Ulmer, The Political Parly Variable in the Michigan Supreme Court, 11 J. PUB. L. 352 (1962).

49. K. LLEWELLYN, supra note 8 , at 462.

50. Beiser, supra note 42 , at 178-79.

51. On leadership, see C. Ducat \& V. Flango, Leadership in State Supreme COURTS: ROles OF THE CHIEF JUSTICE (1976).

52. Merryman, The Authority of Authorily, supra note 1. 
ity at all, and what we think we are measuring when we measure the use of authority. ${ }^{53}$ In any system of social control, power and authority tend to take on, roughly, the shape of a pyramid. Power gets greater and rarer as one climbs toward the top. At the point or tip of the pyramid, some person or institution holds ultimate power. If this is legitimate power, then the holder can make or change law without linking his act to higher authority. A king in an absolute monarchy, a chief in a tribal society, the head of a church-all these may have such power. In a democracy, ultimate authority may rest vaguely in "the law," "the people," or (as in England) in a parliament that represents the people. We are talking not about grand political theory, but about conventional, popular ideas about government. People with power hold it either primarily, or they borrow it from someone higher up in the chain of command. The President, as commander in chief of the armed forces, has primary authority; lower civil servants generally do not. Their sphere of legitimate action is restricted by something higher: regulations, statutes, codes—or some boss.

Judges, generally speaking, have derivative, rather than primary, authority. Even though they have great power, they are not supposed to act free and unfettered. A judicial decision does not stand on its own. According to our legal theory, judges decide "according to law." They are not free to decide cases as they please. They are expected to invoke appropriate legal authority for their decisions. In an obscure but definite way, they are bound to act in a principled manner. It would, for example, be wrong for a judge to let a case turn on a coin toss. This is not a corrupt or evil way to dispose of tough questions, and many of us use it in our everyday life. But it would be out of line for a judge. Nor is a judge supposed to use his own judgment: rather, he is bound by "the law."

What is this "law" that binds the judge? It is found, first of all, in the constitution (federal and state), the state statutes, administrative regulations, and also in precedents from prior cases. Sometimes judges invoke the authority of vague precepts or "principles," referring (for example) to "customary trade practice," or to "a principle of justice so rooted in the traditions and conscience of our people as to be ranked as fundamental," 54 or even to "the interest of the nation." J5 Judges sometimes also cite "secondary" authorities—schol-

53. On the subject of authority and power, see L. FRIEDMAN, The LEGal SySTEM: A SOCLal Science Perspective 234-37 (1975).

54. Palko v. Connecticut, 302 U.S. 319, 325 (1937).

55. McCulloch v. Maryland, 17 U.S. (4 Wheat.) 316, 408 (1819). 
arly treatises, legal encyclopedias, "restatements" of the case law, legislative committee reports, law review articles, and even, on occasion, books and articles that are completely outside "the law."

It is a sign that judges have only secondary authority that they write opinions at all. Judges are expected to justify their decisions. A legislature, passing a statute, has no such obligation. Its words come out as naked fat. But the appellate decision is a reasoned document. It links the result reached with legal premises which have higher authority-the words of a statute, prior case law, or common law "principles." Everybody knows - at least since the realists hammered home the point-that a judicial opinion does not tell us what went on in judges' minds. It may be mere rationalization. But we can say, with some certainty, that the opinion and its reasoning show what judges think is legitimate argument and legitimate authority, justifying their behavior. And such thoughts are important. The sense that judges are "bound" in some way remains strong. There are informal limits on court-ways-vague, mysterious, elusive, but in the end, quite important. These come out of popular understanding, custom, the attitudes of other lawyers and judges, and the judges' own selfimages and theories of what makes a decision legitimate.

Citation patterns thus set forth the authority on which a case rests. They reflect conceptions of role. Changes in these patterns may be barometers of changes in the way judges think about their roles and about the sources and limits of their power. These patterns may be clues, too, to the role of courts in society. ${ }^{56}$

Changes in citation patterns must be interpreted with caution, however. They may reflect technical or organizational changes in the court system as much as or more than they reflect shifts in judicial philosophy. Early in this century, SSCs probably were more dependent on lawyers' briefs for authorities to cite than they are today, for judges now have clerks and good law libraries. ${ }^{57}$ In 1870 , the West Company was not yet printing its regional digests and reports;

56. In his cross-national comparison, Goutal was struck by the heavy reliance in American appellate courts on sheer numbers of earlier cases in support of the result. French courts were content to cite a single statutory provision and no cases. English courts cited some cases, but used them primarily as a beginning point for extended analogical reasoning. American courts, Goutal thought, seemed to rely on a "statistical syllogism" in which the judge notes that a large number of cases have established or followed a particular rule, and then concludes that the instant case therefore deserves the same solution. Goutal, supra note 1 , at 51-55.

57. We should note that law clerks can also affect opinion length. See generally J. Oakley \& R. Thompson, Law Clerks in Judges' Eyes, 67 CALIF. L. Rev. 1286 (1979). 
perhaps that made it harder for lawyers and SSCs to find and cite out-of-state cases. In the late nineteenth century, SSCs in the smaller, new states wrote few opinions and thus had a smaller pool of precedents to draw upon than did high-volume courts in older states. ${ }^{58}$

Judicial work load may also affect citation patterns. One might expect judges in SSCs with very heavy case loads to engage in a narrower search for relevant authority than judges (and clerks) with more time to devote to each opinion. Finally, citation patterns, we must recall, are more than mere matters of style; they also reflect the substantive claims parties bring forward. For example, in the late nineteenth century, common law disputes over debt collection and real property cases dominated SSC dockets. Those types of cases have faded away at the SSC level in recent decades, to be replaced in part by criminal and regulatory cases. ${ }^{59}$ Such changes in SSC work load might raise the number of citations to federal cases, statutes and administrative regulations.

\section{A. Citations to Court Cases: National Trends}

\section{Overall citation frequency.}

Court cases account for the bulk of authorities cited in SSC opinions, and the trend, as shown in Table 6, has been to cite more and more of them. In $1870-1880,75.6 \%$ of SSC opinions cited at least one case, $54.3 \%$ cited at least three, and only $9.3 \%$ cited 16 or more. The mean was 5.8 cases cited per opinion. All these figures climbed steadily over the century. In 1960-1970, the average number of citations in an SSC opinion was $14.3 ; 97.1 \%$ of SSC opinions cited at least one case, $88.6 \%$ at least three cases, and $31.6 \%$ cited 16 or more prior cases.

Table 6 also shows that the number of citations increased even in the "routine" case, as identified by our proxy measure-the absence of citations to the case in subsequent reported opinions. The average "routine" opinion had 3.2 case citations in 1870-1880; this figure was roughly constant during the very high-opinion-load years of $1885-1925$, and then grew, leaping to 9.4 cites in 1960-1970, almost triple the 1870-1880 rate. Citations to prior cases in "important"

58. The way cases are reported may also affect the density of citations. Some state reports printed excerpts from the briefs of the lawyers, including the cases they cited. Perhaps a judge in such a state would feel less need to repeat in his opinion the cases cited by the winning attorney. On the influence of West reports, see also Harris, supra note 17, at ch. 5.

59. See Business of Slate Supreme Courts, supra note 7, at 132-52. 
TABLE 6

Citations to Prior Court Cases, National Trends

\begin{tabular}{lllllll}
$1870-$ & $1885-$ & $1900-$ & $1915-$ & $1930-$ & $1945-$ & $1960-$ \\
1880 & 1895 & 1910 & 1925 & 1940 & 1955 & 1970 \\
\hline
\end{tabular}

Percent of SSC

Opinions Citing:

\begin{tabular}{|c|c|c|c|c|c|c|}
\hline At Least One Case......... & 75.6 & 86.2 & 88.5 & 89.8 & 93.2 & 95.5 \\
\hline At Least Three Cases & 54.3 & 68.1 & 72.0 & 73.3 & 77.9 & 82.9 \\
\hline Sixteen or More Cases ..... & 9.3 & 14.7 & 16.3 & 20.2 & 19.6 & 31.7 \\
\hline Mean Cites $\ldots \ldots \ldots \ldots \ldots$ & 5.8 & 8.3 & 8.9 & 9.8 & 10.0 & 14.0 \\
\hline $\begin{array}{l}\text { Mean Cites in SSC Opin- } \\
\text { ions Subsequently Cited } \\
\text { Once or Never ............ }\end{array}$ & 3.2 & 2.6 & 3.7 & 3.8 & 4.9 & 5.5 \\
\hline $\begin{array}{l}\text { Mean Cites in SSC Opin- } \\
\text { ions Cited by } 12 \text { or More } \\
\text { Subsequent Cases .......... }\end{array}$ & 9.4 & 13.8 & 14.9 & 18.2 & 20.1 & 28.2 \\
\hline
\end{tabular}

SSC opinions - those later cited by 12 or more court cases-also tripled, from a mean of 9.4 in 1870-1880 to a startling 30.8 in 1960-1970, double the number of cites in the average case. Citations in important cases show a persistent upward trend, much like the overall figures. There was a large increase in the late nineteenth century, perhaps reflecting the growth in the volume of citable casés. A big growth surge in citations in important cases came in the late 1940s. Declining opinion load may have played a role in this trend, though the effect is too subtle to show up in aggregate data.

Our data cover both the formalist era of the late nineteenth century and the more policy-oriented modern era. A court that explicitly changed the law might feel compelled to draw heavily on authority, perhaps to try to show respect for tradition in the midst of innovative change. But the effect, if any, of a policy-oriented style on citation patterns is likewise submerged in the general trend. In any event, we expect the number of citations to grow still more, as more SSCs gain discretion to hear only cases they consider important.

\section{Instate, other state, and federal cites.}

The cases cited most often by SSCs are their own prior decisions, as indicated by Figure A. Taking the $1870-1970$ period as a whole, SSCs cited almost two home-grown precedents for every cite to an opinion written by a court of another state. The disparity emerged, however, only in the twentieth century, and has grown wide only in 
recent decades. In 1870-1880, SSCs cited courts from other states slightly more often than they cited themselves or their own inferior courts, although there was considerable variation among SSCs in that respect.

\section{FIGURE A}

Mean Number of Citations Per SSC Case to Prior Instate, Out-ofState, and Federal Cases

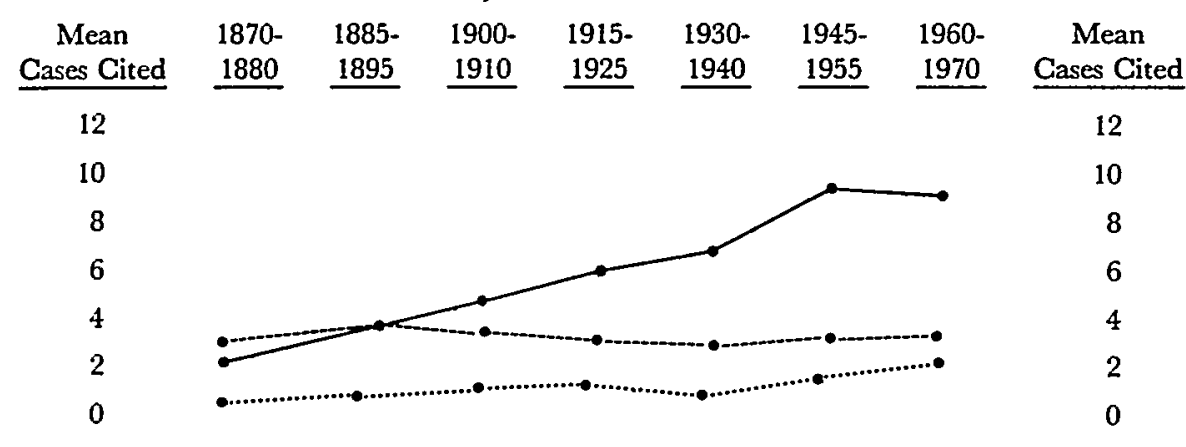

$\begin{array}{ll} & \text { instate cases } \\ \ldots & \text { out-of-state cases } \\ \ldots . . & \text { federal cases }\end{array}$

Figures

$\begin{array}{lllllllll}\text { Instate } & 2.1 & 3.7 & 4.6 & 5.6 & 6.2 & 9.7 & 9.6 & 6.0 \\ \text { Out-of-state } & 2.7 & 3.7 & 3.4 & 3.2 & 3.0 & 3.2 & 3.2 & 3.2 \\ \text { Federal } & 0.4 & 0.5 & 0.7 & 0.9 & 0.7 & 1.1 & 1.9 & 0.9\end{array}$

Since 1870-1880, however, while citations to instate cases have more than quadrupled (from a mean of 2.1 per opinion in 1870-1880 to 9.6 in 1960-1970), citations to other state opinions have stagnated, holding at a mean of three cites or slightly higher. This is, we suspect, not what most people would have guessed. Communications have improved, legal libraries have grown, and states have probably lost some of their cultural diversity. Yet, SSCs have not become more likely to treat the opinions of other states as relevant authorities. They are much more likely to invoke their own decisions.

The tendency to cite more instate as compared to out-of-state cases might reflect the relative decline of common law cases on SSC dockets and the growth of statutes as a source of law. In interpreting the statutes of its own state's legislature, an SSC has less reason to consult decisions in other states. Indeed, as shown in Table 7 below, 
statute citation is significantly higher in the $1940-1970$ period. But the growth of instate case citations in the 1870-1940 period is not matched by a comparable increase in citations of statutes, so this cannot be the whole answer. The decline of out-of-state citations in proportion to instate cites may also reflect the tendency of court and counsel to follow a practice of preferring instate precedents; courts (and counsel) apparently turn to out-of-state sources only when instate cases are absent or ambiguous. As the pool of instate precedents grows, there are fewer occasions for out-of-state cases. The state-bystate data provide some support for this hypothesis.

\section{TABLE 7}

Citations to Statutes, Administrative Regulations, and Rules of Judicial Procedure
$\underline{1870-1900}$
$1905-1935$
$\underline{1940-1970}$

SSC Cases

with Cites to:

Statutes .......

$\frac{\mathrm{N}}{746} \quad \frac{\%}{48.4} \quad \frac{\mathrm{N}}{759} \quad \frac{\%}{50.3} \quad \frac{\mathrm{N}}{1055} \quad \frac{\%}{67.2}$

Administrative

Regulations ....

6

0.4

15

1.0

39

2.5

Rules of Judicial

Procedure......

213

13.8

186

12.3

314

20.0

None of Above .

667

43.3

635

42.1

389

24.8

Cases in Sample

1542

$105.9 \% *$

1510

105.7\%*

1570

$114.5 \% *$

* Total exceeds $100 \%$ because of cases that cited statutes and regulations or rules of court, or all three.

First, however, we note how few citations to federal cases (including U.S. Supreme Court cases) there are. As Figure A shows, throughout the 1870-1940 period fewer than one federal citation appeared, on average, in each SSC opinion. Federal citations have been sharply increasing in recent decades, as federal law penetrates state cases, especially criminal cases. Still, federal cites remained much less frequent than cites to other state courts, averaging 1.9 per SSC case (1960-1970) and 3.1 per SSC criminal case (1940-1970). ${ }^{60}$

English cases had some currency in SSCs even in the late nine-

60. After criminal cases, federal citations in SSC cases in the 1940-1970 period were most frequent in contract cases, where they appeared a mean of 1.8 times. This does not mean that federal law has become more important in contract cases; rather, an increasing number of "heavy" contract cases find their way into federal courts under diversity jurisdiction as interstate commerce expands. Because of the decision in Erie R.R. v. Tompkins, 304 U.S. 64 (1938), federal courts decide these cases under state law. Thus, federal case cites in 
teenth century. Citations to other countries, even neighboring Canada, have been very, very rare. In 1870-1900, a foreign (primarily English) case was cited in only $15.3 \%$ of SSC cases; the practice of citing foreign cases has since become more and more attenuated. In one volume of Tennessee Reports (No. 124) for 1910-1911, the court cited more than 600 cases from Tennessee, more than 200 from other American states, but only 12 English cases. In 1900-1935, foreign cases were cited in only $5.4 \%$ of SSC cases, and by $1940-1970$, in only $3.1 \%$. In $1870-1900$, there were 35 cases in our sample that cited eight or more foreign cases; in 1940-1970 there were none. England and the United States are linked by jet and satellite; but in terms of court citations, the two countries have drifted apart.

\section{B. Interstate Variation in Case Citations}

\section{Overall citation frequency.}

SSCs increasingly resorted to court cases over the century; Table 8 presents the data. The growth of case citations in some SSCs was more dramatic than in others; the Idaho Supreme Court averaged only 3.6 case cites per opinion in 1870-1900 (half the 16-state mean of 7.2), but averaged 18.2 cites in 1940-1970, well above the 16-state mean of 13.7. Over the same years the California Supreme Court went from a paltry 4.4 case-citation average to a high of 22.1. Rhode Island is the sole SSC in our sample that steadily cited ferer cases over time; its rate was above average in 1870-1900 (8.1); this sagged to 6.4 cites (half the 16 -state mean) in $1940-1970 .^{61}$

A large case load appears to have some negative influence on the number of case citations. In the 1870-1900 period, for example, SSCs that wrote fewer than 150 opinions a year-the smaller New England and Western SSCs, plus New Jersey and West Virginia (which had an IAC and discretion, respectively) - tended to have case-citation averages above the mean, although Idaho and Oregon were exceptions. The high case-load SSCs in larger states, with the exception of Alabama, cited fewer cases per opinion than the 16-state mean. The case-load/citation relationship was not so strong in the 1905-1935 period, however, as more low case-load SSCs (New Jersey,

SSCs do not always show federal penetration of state law; they sometimes show state penetration of federal case law.

61. South Dakota's SSC reduced cites from 9.0 in $1870-1900$ to 5.8 in $1905-1935$, but then increased them to 8.9 per case in 1940-1970; Tennessee's SSC reduced its case citation rate to 9.0 per case in 1940-1970, as compared to 12.7 in 1905-1935, but showed an increase in cites between 1870-1900 and 1905-1935. 
Rhode Island, South Dakota) slumped below the 16-state average and more high case-load states (such as California, Illinois, and North Carolina) cited more cases than average. By the 1940-1970 period, there was more variation within each of the three groups of SSCs in Table 8 than between them.

Discretion to concentrate on more "important" cases seems to push case-citation levels upward. Since 1872, West Virginia's SSC has had discretion to reject appeals it believes to be without substantial merit. In 1870-1900, as the only SSC in our sample with such broad discretion, it averaged 13.5 court cites per opinion, far more than any other SSC and almost twice the 16-state mean of 7.2. In 1940-1970, West Virginia averaged more than 18 cites per case, exceeded only by New Jersey and California, the only other states that exercised strong case-selecting discretion throughout that period. North Garolina instituted an IAC system in 1967 and granted its supreme court discretion to concentrate on "truly significant questions of law"; 62 its citation rate in 1970 opinions was double the 1960 and 1965 rate. ${ }^{63}$ New Jersey's high court has had an IAC buffer ever since 1844 , but its average level of case citations tripled to more than 20 per opinion after a 1948 constitutional reform gave it case-selecting discretion-and new leadership. Chief Justice Arthur Vanderbilt required each New Jersey Supreme Court judge to prepare (or have his clerks prepare) a conference memorandum for each case. ${ }^{64}$ This obviously stimulated legal research. In 1960-1970, the New Jersey Supreme Court averaged 27.9 case citations per opinion. California's case-citation level doubled to 22.1 per case in the $1940-1970$ period after it began exercising strong control over the choice of cases to hear; in addition, a mini-bureaucracy of permanent clerks and law student "externs" prepared prehearing memoranda for each case. ${ }^{65}$ By 1970 , even the average per curiam opinion issued by the California Supreme Court contained 18 case citations (triple its 1960 rate for per curiams and six times the 1950 rate) ${ }^{66}$ States with IACs that publish opinions have, of course, an extra pool of cases for courts (and lawyers) to cite.

62. Groot, supra note 28 , at 554 .

63. The Michigan SSC, which gained discretion in 1964, averaged 14.7 cites per sampled case in 1970, while its 1940-1970 average was only 8.7 .

64. A. Vanderbilt II, Ghanging Law: A Biography of Arthur T. Vanderbilt 171-73 (1976).

65. See Goodman \& Seaton, Foreword: Ripe for Decision, Intemal Workings and Current Concerns of the California Supreme Court, 62 CaLIF. L. REv. 309, 312-13 (1974).

66. Merryman, Toward a Theory of Citations, supra note 1, at 392. 
The California and New Jersey Supreme Courts, as noted earlier, were known in the 1950s and 1960s as modern "legal realist" courts. Do their high rates of case-citation reflect not only structure (IACs), but judicial philosophy as well? By way of contrast, we have the Rhode Island Supreme Court, whose judges saw themselves in traditional terms as "law appliers," even in $1970 .{ }^{67}$ Rhode Island cited scarcely one-third the number of cases that California and New Jersey did. ${ }^{68}$ We cannot test the influence of judicial philosophy on citation levels through our data; that would take, at the very least, some qualitative study of opinions and results. The legal realists, as scholars, were profoundly skeptical of the authority of precedents; it would be ironic if their influence led courts to cite more and more prior cases.

\section{Citations to instate vs. out-of-state cases.}

Each SSC owes highest allegiance to its own case law, but also makes liberal use of outside cases. As indicated by Figure A, and shown in another way in Table 8, out-of-state citations account for roughly $40 \%$ of all case citations in the $1870-1970$ period. Referring to out-of-state cases has not been indiscriminate, however; as we shall see, there are favorites, "stars" of the citation world, and some wallflowers too-courts that other courts rarely cite. Moreover, the percentage of out-of-state cases cited has declined over time, from $57 \%$ of all cites in $1870-1900$ to $43 \%$ in $1905-1935$, and $33 \%$ in $1940-1970$. And for the entire 1870-1970 period, more than half (55\%) of the cases in our 5,900-case sample cite no out-of-state cases. Still, out-ofstate cases are cited often-24,956 times, to be precise (out of a total of over 60,000 cites in the 5,900 cases) - enough to support the idea that SSCs regard themselves as siblings of a single legal family, speaking dialects of a common legal language. On the other hand, SSCs have differed considerably in their out-of-state citing practices. Table 8 displays these differences.

67. See note $\mathbf{5 0}$ supra and accompanying text.

68. Rhode Island had both a low citation rate and a low dissent rate. So did Tennessee in 1940-1970. Conversely, New Jersey, California, Idaho, and West Virginia all had high citation rates in 1940-1970 and above-average rates of divided opinions. Does division encourage the majority to search more broadly for support and cite what it finds? The data do not always support this notion, at least at the aggregate level. The Michigan Supreme Court had a very high dissent rate and a very low citation rate in 1940-1970, as did the Tennessee Supreme Court in 1905-1935. Alabama was low in dissent but above average in citations in all periods. 


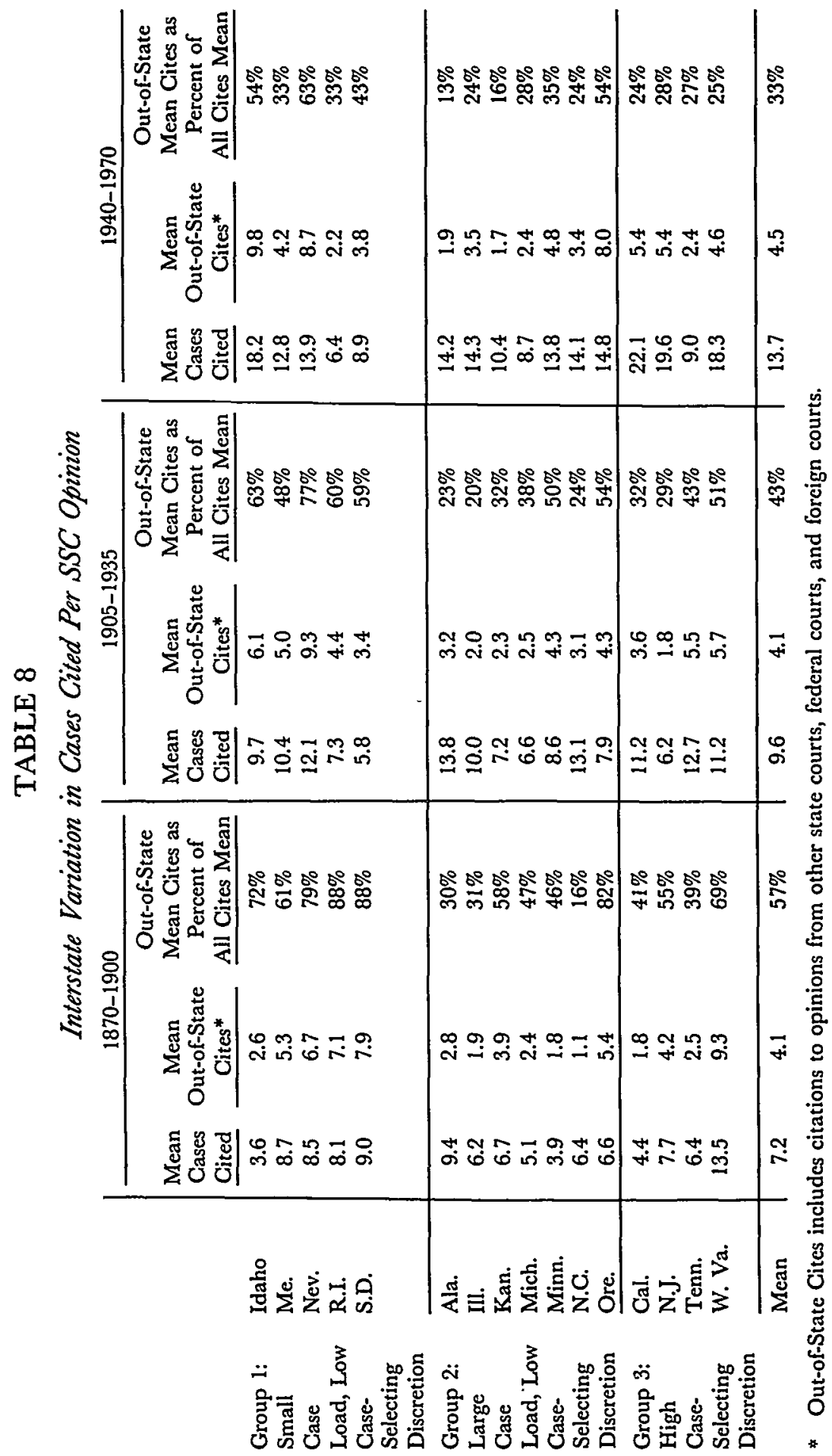


In the late nineteenth century, states east of the Mississippi cited themselves heavily. For some reason, Southern states were especially parochial. Only $16 \%$ of North Carolina's citations in 1870-1900 were from out-of-state courts; the comparable figures for Alabama and Tennessee were $30 \%$ and $39 \%$, at a time when the 16 -state mean for out-of-state citations was $57 \%$ of all cites. One deviant case was Rhode Island, as old and as Eastern as they come; it relied heavily on other courts-especially its neighbor, Massachusetts.

Smaller Western states, on the other hand, usually looked to other SSCs for relevant authority. At least $70 \%$ of the cases cited by the Idaho, Nevada, South Dakota, and Oregon SSCs in 1870-1900 were from other states. These SSCs, after all, were quite raw and new. They simply did not have much home authority to cite. Only about six volumes of Idaho cases were published before 1900. Small wonder, then, that Idaho cited California twice as often as it cited itself. (California, population giant of the West, already had a huge pool of its own cases to cite, and was more likely to cite its own than out-of-state cases.) West Virginia, too, was a new state, recently chopped out of Virginia. Sixty-nine percent of its voluminous citations were from other states; Virginia, as one might expect, was heavily cited (and in a sense, older Virginia cases were not out-of-state for West Virginia at all).

Patterns for 1905-1935 resembled those of the late nineteenth century. Except for Rhode Island, it was still the newer states that cited more outside cases than inside ones-Nevada, Idaho, Oregon, South Dakota, and West Virginia. The proportion of out-of-state cites had begun to decline, however, as the volumes of home-grown cases grew on the shelves of these states. South Dakota declined from a mean of 7.9 out-of-state cites (88\% of all cites, 1870-1900) to 3.4 (59\% of all cites, 1905-1935). Oregon went from 5.4 (82\%) to 4.3 (54\%). Still, some Western states never dropped the custom of citing their neighbors. Tiny Nevada's figures are 6.7 (79\%), 9.3 (77\%), and in 1940-1970, 8.7 (63\%).

In the most recent period (1940-1970), Nevada, Idaho, and Oregon were the only states which continued to cite more out-of-state than instate cases. Kansas had joined Alabama in looking almost entirely inward; it averaged only 1.7 out-of-state cites per opinion, about $16 \%$ of its total case citations. Do "modern," policy-oriented courts with IACs and the capacity to restrict themselves to "important" cases engage in a wider search for authority? California and New Jersey, the exemplars of this type of SSC, each cited an average 
of 5.4 out-of-state cases per opinion in the $1940-1970$ period (24\% and $28 \%$ of all cites, respectively). This was above average in number of cites, but below average in citation percentage. The evidence, therefore, suggests that these factors have only a weak effect on out-of-state citation patterns.

We should emphasize, however, that sheer numbers of citations are only the roughest indicator of legal style or breadth of research. A judge who cites many cases has not necessarily done more research than a judge who cites only a few. Many decisions "string" out long lists of cases. From our rough figures, it is impossible to tell whether judges read and studied the cases, or why they thought it was better to cite 10 cases than two, or in what sense the cited cases influenced the court's result. More precise, surgical analysis of cases does not help very much. In Zimmerman v. Harris Lumber Co. ${ }^{69}$ a 1960 Idaho case of no particular distinction, a millwright died on the job of a heart attack. The question was whether workmen's compensation should be paid. The court said no. The Workmen's Compensation Board had "found" that Zimmerman "did not suffer an accident in the course of his employment." There was "substantial evidence" on both sides of the issue; the court felt bound to affirm the board's decision. Having said this, the court then listed 16 Idaho cases supporting the fairly bland doctrine it announced (its duty to defer to the board). ${ }^{70}$ We can assume that these cases were individually unimportant to the Zimmerman decision-and we cannot be sure they meant much in the aggregate. Yet, had the court held the other way, it might have made do with one or two strong out-of-state cases.

\section{Which SSCS are cited?}

SSCs do not draw equally on courts of all their sister states when citing out-of-state cases. Peter Harris has extended our data by studying the interstate citation network. ${ }^{71}$ In the $1870-1880$ period, the network featured three "stars." SSCs, in our sample of courts, cited New York, Massachusetts, and California far more than they cited other SSCs. New York alone received $26 \%$ of all out-of-state cites. Harris noted that "stars" in the citation network, once established, continue to shine: Once a case from a state's court was cited favorably in another state, it became part of the common law of that state, and the chance that the out-of-state court would cite it again would

69. 82 Idaho 187,350 P.2d 746 (1960).

70. Id . at 190-91, $350 \mathrm{P} .2 \mathrm{~d}$ at 747 .

71. P. Harris, supra note 17. 
go up accordingly. ${ }^{72}$

Over the decades, however, citations became more equally distributed. In 1885-1895, New York was still cited most often, but it accounted for only $15 \%$ of SSC references to out-of-state courts during the period. Massachusetts was in second place, accounting for $13 \%$ of cites, but its geographic sphere of influence was shrinking; Massachusetts cites were confined mostly to New England SSCs. California was increasingly cited by SSCs outside its western sphere of influence. By 1915-1925, New York accounted for only 9\% of outof-state cites. Midwestern SSGs such as Illinois, Michigan, and Wisconsin, along with Pennsylvania, were more widely cited.

In 1945-1970, California moved into first place. Thirteen percent of all out-of-state cites in our sample of cases were California cites; this compares to New York's 8\%. The SSCs of New Jersey, Illinois, and Texas were also cited with special frequency by other courts. California's total was high, in part, because it was cited so often by nearby Idaho, Nevada, and Oregon. These SSCs cited other SSCs at a high rate, in a period in which most SSCs were relying on their own stock of prior cases. In any event, in 1940-1970, 92\% of the California Supreme Court cases in our sample were cited at least three times by out-of-state courts; $26 \%$ were cited in more than eight subsequent out-of-state opinions. By way of contrast, Rhode Island was the least cited SSC of our 16; only $39 \%$ of its opinions in 1940-1970 were cited in three subsequent out-of-state cases, only $6.4 \%$ in more than eight.

Taking the 100 years from 1870 to 1970 as a whole, the variation in citations to SSCs in different states has been substantial. Table 9 shows how many times our sample of 5,900 cases cited (as out-of-state cites) the 16 SSCs in our study. We added cites to New York and Massachusetts, two of the most cited courts, and Delaware, one of the least cited courts. ${ }^{73} \mathrm{New}$ York opinions were cited 2,356 times; California, 1,848; Alabama, 319; Rhode Island, 101; and Delaware, 50. To some extent, variation would be natural and expected; some states, like New York and California, have many more cases that might be cited than Delaware or Idaho. Larger states not only produced more SSC opinions; they also published IAC opinions that could be cited. Still, the disparity in numbers of citable cases from Delaware (an old state), say, compared with New York, is less than

72. Id. at ch. 1 .

73. The only SSCs cited less often than Delaware were Wyoming (36) and the new SSCs of Hawaii (10) and Alaska (1). 
the difference between actual citations to the two courts. The same applies to the disparity between Massachusetts and Maine.

\section{TABLE 9}

\section{Frequency of Citation by Out-of-State Courts, 1870-1970}

\begin{tabular}{|c|c|c|c|c|c|c|c|c|}
\hline State & $\begin{array}{c}\text { No. } \\
\text { Cites* }\end{array}$ & $\begin{array}{c}\text { 50-State } \\
\text { Rank } \\
\end{array}$ & State & $\begin{array}{l}\text { No. } \\
\text { Cites } \\
\end{array}$ & $\begin{array}{c}\text { 50-State } \\
\text { Rank } \\
\end{array}$ & State & $\begin{array}{l}\text { No. } \\
\text { Cites }\end{array}$ & $\begin{array}{c}\text { 50-State } \\
\text { Rank }\end{array}$ \\
\hline N.Y. & 2356 & 1 & Kan. & 334 & 19 & W. Va. & 131 & 38 \\
\hline Cal. & 1848 & 2 & Ala. & 319 & 20 & R.I. & 101 & 42 \\
\hline Mass. & 1564 & 3 & N.C. & 297 & 21 & S.D. & 75 & 43 \\
\hline Ill. & 877 & 4 & Or. & 289 & 23 & Nev. & 69 & 44 \\
\hline Mich. & 547 & 10 & Me. & 262 & 27 & Idaho & 67 & 45 \\
\hline N.J. & 457 & 12 & Tenn. & 226 & 30 & Del. & 50 & 47 \\
\hline Minn. & 436 & 14 & & & & & & \\
\hline
\end{tabular}

* Number of citations to the named state in the sampled SSC cases. The sample was 5,904 cases with respect to N.Y., Mass., and Del., the states that were not in our sample of 16. The sample was 5,526 for the 16 sampled states; we excluded instate cases from the sample for the state in question. The figures were adjusted to reflect this difference in sample size. See P. Harris, supra note 17, at ch. 6.

Some sort of "prestige" factor, independent of population, must be involved. In the 1940-1970 period, there was no increase in the frequency with which the decisions of 14 of our SSCs were cited by other SSCs. The two exceptions were California and New Jersey. These SSCs had discretion to select "important" cases; they wrote longer opinions, had frequent dissents, and cited more cases than the others. They had reputations as innovative policy makers. These factors, as much as the size of the states or the volume of their opinions, may explain why other SSCs cited them so often. ${ }^{74}$

Population and reputation are probably related, though in a rather subtle way. California Supreme Court decisions establish the law for an empire of over 20,000,000 people; for that reason alone, California decisions may be regarded as more significant than the decisions of the SSC of South Dakota, a state with a population about $4 \%$ that of California's. California's size and dynamism probably spurred the growth of its court's influence as much as the reputation of its judges—or more.

Overall, however, the "star" system has faded over the century from 1870 to 1970. As Harris showed, centers of influence and authority became more widely diffused. In our sample of cases, every

74. In the $1950-1970$ period, only 20 cases in our sample of 1,440 were cited 14 or more times by out-of-state SSCs. Of the 20 , New Jersey and California each contributed four, Illinois, three. 
one of our 16 SSCs had at least one case that reached the top $2 \%$ in number of subsequent out-of-state cites; 10 of the SSCs had at least eight cases in that category. ${ }^{75}$ There were recognizable regional groupings and regional leaders, however. SSCs cite SSCs with which they are joined in West's regional reporters more often than SSCs in other "regions." And SSCs also lean toward SSCs of states from which many of their people had migrated. ${ }^{76}$

Finally, Harris's study shows a growing tendency for SSCs to cite more recent out-of-state cases. Overall, there are more citations in our sample to older cases, simply because an 1890 case has had many more opportunities to be cited than a 1965 case. Thus, the average SSC case in our 1870-1900 sample was cited 7.6 times by later appellate cases in its own state and four times by out-of-state courts; for 1940-1970 cases, the figures were 5.9 subsequent instate cites and 1.5 out-of-state cites. But over time, older precedents have become relatively less attractive, and more recent ones have become relatively more attractive. In our 1870-1880 sample, only $20 \%$ of the cites to out-of-state cases were to opinions less than 10 years old; $50 \%$ were to opinions more than 25 years old. In the 1960-1970 sample, by contrast, $40 \%$ of the out-of-state cites were to opinions less than 10 years old, and only $35 \%$ were to opinions more than 25 years old. ${ }^{77}$

The nonlawyer thinks that the citing of precedent is a sign of ancestor-worship, of deep conservatism. This is reinforced by occa-

75. The numbers of cases in the sample cited 14 or more times by out-of-state courts, by SSC, were as follows: New Jersey (20), Illinois (16), Minnesota (14), Michigan (13), Maine (13), Kansas (12), Nevada (11), West Virginia (11), California (10), Tennessee (9), Rhode Island (8), South Dakota (6), Oregon (4), Idaho (3), Alabama (2), North Carolina (1).

76. On the diffusion of centers of influence, see P. Harris, supra note 17, at ch. 6 ; on the effects of the West system and migration patterns, see $i d$. at ch. 5 .

77. Merryman's figures on cites by the California Supreme Court suggest a "citation half-life" of such cases of about seven years-that is, "the probability that any decision of the California Supreme Court will be cited by that court as an authority is reduced by one-half every 7 years or so." The drop from the first to second decades is particularly sharp. Merryman, Toward a Theory of Citations, supra note 1, at 395 n.1. See also Landes \& Posner, Legal Precedent: A Theoretical and Empirical Analysis, 19 J.L. \& ECON. 249 (1976).

Cases involving government regulation of business, torts, and family law tended to cite more recent out-of-state cases than opinions involving estate law, corporate law, contracts, real estate, and crimes against property, which tended to cite older out-of-state cases, on the average.

Opinions in criminal law cases tended to cite more out-of-state cases than the average: 5.2 out-of-state cites compared with a mean (for the whole sample) of 4.2 cites. Murder opinions averaged 5.4 out-of-state cites. Corporation cases (5.2) and commercial contract cases (4.8) also cited more broadly than average. Family law (3.6), real property law (3.6), and collection cases (3.7) averaged fewer out-of-state cites than the 4.2 mean. Tort opinions were about average in out-of-state reach for authority. 
sional loose talk from jurists. Justice Holmes, who should have known better, said that it was "revolting" to follow a rule simply because it was laid down in the days of Henry IV, ${ }^{78}$ as if the legal system really behaved that way. Lawyers know that what courts want is not the oldest case, but the freshest, since it is usually the most relevant. Legal problems come to the court in concrete forms; they rarely wear the clothing of ageless, abstract principle. Consequently, it is no surprise that the best guidance-and the best legitimation-tends to come from case law which presents concretely similar problems. In the nature of things, these are recent cases. The data support this view.

\section{Citations to Statutes, Regulations, and Rules of Court}

\section{National trends.}

SSC opinions have not cited statutes and regulations as often as they have cited court cases. But even in the late nineteenth century, when most SSC cases arose in common law areas (contracts, real property, torts), almost half (48.4\%) of the cases in our sample cited statutes, as shown by Table 7. Closer consideration of the areas of law involved helps explain why. During 1870-1900, 12.4\% of SSC cases were in public law fields (taxation, election law, etc.), topics largely governed by statute; $10.7 \%$ of SSC matters were criminal cases. Most states had long since enacted penal codes; common law crimes were abolished or severely restricted. Contract cases made up $33 \%$ of SSC dockets, but three-fourths of those were debt collection cases, and many of these involved insolvency proceedings, garnishments, mortgage foreclosures, or executions of judgments-complex areas of law regulated to a considerable extent by statute. Similarly, real property cases, which accounted for $21 \%$ of SSC cases in 1870-1900, often turned on statutes concerning government land grants, registration of titles, and Statutes of Frauds. ${ }^{79}$

In the twentieth century, the subject matter of SSC cases shifted away from staple common law fields. Moreover, statutory prescriptions invaded almost every area of law. Workmen's compensation statutes pushed aside the common law of industrial accidents. Commercial law was codified. The growth of legislation is apparent even to the naked eye: The collected statutes of a nineteenth-century state usually consist of one fat volume; such collections today are 10 or 20

78. Holmes, The Path of the Law, 10 HaRv. L. Rev. 457, 469 (1897).

79. See Business of State Supreme Courts, supra note 10, at 140-141. 
times as large in sheer bulk. Of course, statutes often leave a long trail of judicial opinions that elaborate what they mean; a common law court has great power to undo or extend the reach of an enactment through creative "interpretation." But we would expect citations of statutes themselves to have grown steadily throughout the century. Surprisingly, however, the proportion of SSC cases that cited statutes hardly grew before the 1940 s. It hovered just above $50 \%$ through the first four decades of the century. In the 1940-1970 period, the percentage of cases with statutory cites climbed to just over $67 \%$; but this growth merely paralleled the growth of criminal and public law cases on SSC dockets. ${ }^{80}$ Moreover, despite the enormous growth of government bureaucracies and administrative decisionmaking, only $2.5 \%$ of SSC cases in 1940-1970 cited administrative regulations. Even in 1960-1970, the most recent period, about $30 \%$ of SSC cases cited neither statutes nor administrative regulations-as if they were operating in the realm of "pure" common law. ${ }^{81}$

Even to say that $70 \%$ of $1960-1970$ cases cited statutes may overstate their impact. Many cases, of course, turn entirely on the meaning or validity of a statute. In other cases, however, the cite may be routine or perfunctory - the mere mention, for example, of that part of the judiciary act that relates to the court's jurisdiction over the appeal. In $1870-1880,76.9 \%$ of the Alabama cases in our sample cited statutes, but many cites were of this technical sort. In $1960-1970,81 \%$ of the California Supreme Court cases cited statutes or regulations, more than any other court among our 16 (Illinois was

80. From $1905-1935$ to $1940-1970$, criminal law cases grew from $6.6 \%$ to $18.2 \%$ of all SSC opinions; public law cases grew from $6.4 \%$ to $19.4 \%$ of SSC cases; and workers' compensation cases grew from $3.6 \%$ to $6.4 \%$ of cases. Together, then, these "statutory" areas grew $16.6 \%$, just about the same as the growth in the percentage of SSC cases that cited statutes. Overall, however, these three "statutory" areas made up only $44 \%$ of all SSC cases, while statutes were cited in $67 \%$; hence many cases in "common law" areas continued to cite statutes with some frequency.

81. There may be some undercounting of statutes in our data. It is easier to overlook a statutory cite than a case cite; we cannot be sure that our coders always picked up stray references to a "school law" or the "procedure code." Sometimes, a court implies a statute without citing it. These cases almost certainly wriggled through the meshes in our coders' nets. A South Dakota case in 1895, for example, turned on whether the plaintiff was entitled to a certain kind of remedy. The court said no. The plaintiff's original complaint was "equitable," thus he could have only equitable relief, even though the old forms of action and many procedural distinctions between law and equity had been abolished. Anderson v. Chilson, 8 S.D. 65,64 N.W. 435 (1895). The court did not cite any statute, but the opinion plainly implied various pieces of the code of procedure. The contemporary Alabama Supreme Court, for one, might well have peppered its opinion in a similar case with references to statutes; it cited statutes in $67.4 \%$ of all cases in $1885-1895$. 
the laggard, at 59\%). But many of these citations were peripheral to the main issue. We do not know how often a case tumed on the cited statute. But the same could be said, of course, about case citations. Therefore, unless fewer statutory cites in recent decades were important to the decision than was the case in earlier time periods, our data show a growing role for statutory authority. ${ }^{82}$

\section{Interstate variation.}

Our data show wide variation among states in how frequently statutes are cited, but few patterns that we can point to "explain" the variation. A few Western states, such as California, Idaho, and Nevada, adopted comprehensive "codes" in the nineteenth century. These codes purported to set down basic common law principles in statutory form. Codes were particularly welcome in the West, where states were new and underpopulated, and a neat, complete package of statutes that could be enacted quickly was especially appealing. Whether codification made any difference to the behavior of SSCs has long been disputed. Our data show that the Idaho Supreme Court cited statutes in $71 \%$ of its late nineteenth-century cases, far above the $48.4 \%$ average, but that Nevada (57.6\%) and California (53\%) were only slightly above the mean. Kansas (61.8\%) and South Dakota $(66.6 \%)$, newer Western states without codes, also cited statutes often. New Jersey, which cited statutes in only $33.3 \%$ of its cases, was the most completely "common law" state, ${ }^{83}$ but other Eastern states, such as Maine and Rhode Island, were about average. North Garolina cited statutes in only $37 \%$ of its $1870-1900$ cases, but Alabama, another older, Southern state, cited statutes in 65\%. In the twentieth century, however, interstate variation declined; SSCs looked more alike in frequency of statutory citations.

\section{Gitations to Secondary Authorities}

\section{A. Treatises and Encyclopedias}

We turn now to so-called secondary authorities, and first to legal treatises and encyclopedias. As Table 10 shows, from 1885 on, about

82. One caution: There is, it seems, a general increase in citing; perhaps the increase in cites to statutes merely reflects the general trend, aided and abetted by eager clerks. If so, just as the dollar is worth less, more statutory cites today are peripheral or superfluous, as compared to statutory cites in earlier decades.

83. In the $1870-1880$ period, only $22.4 \%$ of the Illinois cases cited statutes, but that figure jumped to $55 \%$ in $1885-1895$. For the whole $1870-1900$ period, the Illinois Supreme Court cited statutes in $48.2 \%$ of cases. 
two-fifths or more of SSC opinions cited these authorities. But most older treatises did no more than compile cases; they wrapped the confusion of prior case law into a convenient package, usually in the form of black letter rules. ${ }^{84}$ The 1890 Minnesota Supreme Court tells us that a certain doctrine was law "in the greater number of American cases. 2 Pom. Eq. Jur. § 618." 85 An Alabama case, same year, looked to "Drake on Attachments," 6th edition, to find out "[t]he numerical weight of the adjudged cases . . . as will be seen from the authorities cited by Mr. Drake."86 In 200 pages of Alabama reports in 1890 , the court cited 24 different legal treatises, some of them more than once (Dillon on Municipal Corporations, Pomeroy, High on Injunctions, Taylor on Landlord and Tenant). All were strictly "legal," and the cites simply summed up case law. A New Jersey case of 1875, on a procedural point, quoted "Gould on Pleading, ch. 7, § 9": "The traverse de injuria, $\mathcal{E}^{2} c$, absque tali causa, though of frequent occurrence, is confined to actions ex delicto, and used only in replications." 87 Gould may have helped the court, but he hardly broadened its horizons.

TABLE 10

Citations to Secondary Authorities

$\begin{array}{lllllll}1870- & 1885- & 1900- & 1915- & 1930- & 1945- & 1960- \\ \underline{1880} & \underline{1895} & \underline{1910} & \underline{1925} & \underline{1940} & \underline{1955} & \underline{1970}\end{array}$

Percent of SSC

Opinions Citing:

$\begin{array}{llllllll}\text { Law Reviews............. } & 0.5 & 0.3 & 0.4 & 0.5 & 2.3 & 3.8 & 11.9\end{array}$

Treatises, Encyclopedias,

$\begin{array}{llllllll}\text { Restatements, etc. ........ } & 32.7 & 43.1 & 46.6 & 44.1 & 42.2 & 47.2 & 39.2\end{array}$

In the twentieth century, some SSCs developed the habit of citing the giant encyclopedias, Corpus Juris and American Jurisprudence; some cite American Law Report (A.L.R.) annotations. The Idaho Supreme Court is prolific in citing secondary authority. But what is cited is very ordinary lawyer's law. For example, in State v. Cox, a 1960 case, the court refers to Bell's Handbook of Evidence for the Idaho Laweyer, three

84. Not all treatises, to be sure, were mere compilations. Some attempted to provide an analysis, or even devise a policy or two. The treatises of Story or Bishop (or Wigmore at a later period) are of this type.

In the late nineteenth century, a few cites of English classics-Blackstone and Lord Coke-were scattered about in our sample of opinions, but these worthies were endangered species by the end of the century and are now, to all intents and purposes, extinct.

85. Wilkins v. Bevier, 43 Minn. 213, 216, 45 N.W. 157, 158 (1890).

86. Cartwright v. Bamberger, 90 Ala. 405, 408, 8 So. 264, 265 (1890).

87. Ruckman v. Ridgefield Park R.R., 38 N.J.L. 98, 100 (1875). 
A.L.R. annotations, and Corpus Juris Secundum.$^{88}$

As might be expected, there has been considerable interstate variation in propensity to cite legal texts, as shown in Table 11. The variability, however, does not follow a neat or predictable pattern. The Idaho Supreme Court, in its youth (1890-1900), and with only a tiny stock of local cases to cite, referred to legal writings in only $19 \%$ of its cases, last among the 16 SSCs. In 1940-1970, with a large stock of its own precedents to draw upon, it cited treatises and encyclopedias in $73.4 \%$ of its cases, first among the 16 .

To some extent, an SSC's record in treatise-citing paralleled its case-citing record. Just as the Rhode Island Supreme Court cited fewer cases as time passed, so did its resort to treatises decline, from $39.8 \%$ of $1870-1900$ cases to $21.5 \%$ of $1940-1970$ cases. Oregon, always a busy citer of out-of-state cases, also was near the top in treatise-citing. The big-state, high case-load SSCs-perhaps because they had a wealth of instate precedent to draw on-were more diffident about citing treatises in their opinions. But there are great variations within clusters or types of SSCs, as grouped by case load and discretion.

\section{B. Law Reviews}

If treatises and encyclopedias were cited often, law review articles, which at least sometimes have been more imaginative, hardly appeared in SSC opinions until recent years. This is not surprising. Law reviews as we know them today, sponsored by law schools and edited by an elite corps of students, hardly existed before the end of the nineteenth century. ${ }^{89}$ The first volume of the Harvard Law Review appeared in 1887. This was the inspiration for a vast brood of journals, but most did not appear until the twentieth century. Even in the 1900-1930 period, less than 1\% of SSC opinions cited law reviews; in 1945-1955, fewer than $4 \%$ did so. Only in the most recent period, 1960-1970, has there been significant change. Law reviews were mentioned in almost $12 \%$ of SSC opinions, and their dramatic rise of $8 \%$ from the preceding period was matched by an $8 \%$ decline in citations to treatises and encyclopedias. The New Jersey Supreme

88. 82 Idaho 150, 351 P.2d 47 (1960).

89. There were few legal periodicals of any sort in the nineteenth century. Before the West Company developed its reporting and indexing system, law magazines served the profession by printing important cases, often adding comments. One or two, like the lively Green Bag, contained general matter interesting to lawyers, including anecdotes and bits of history. 


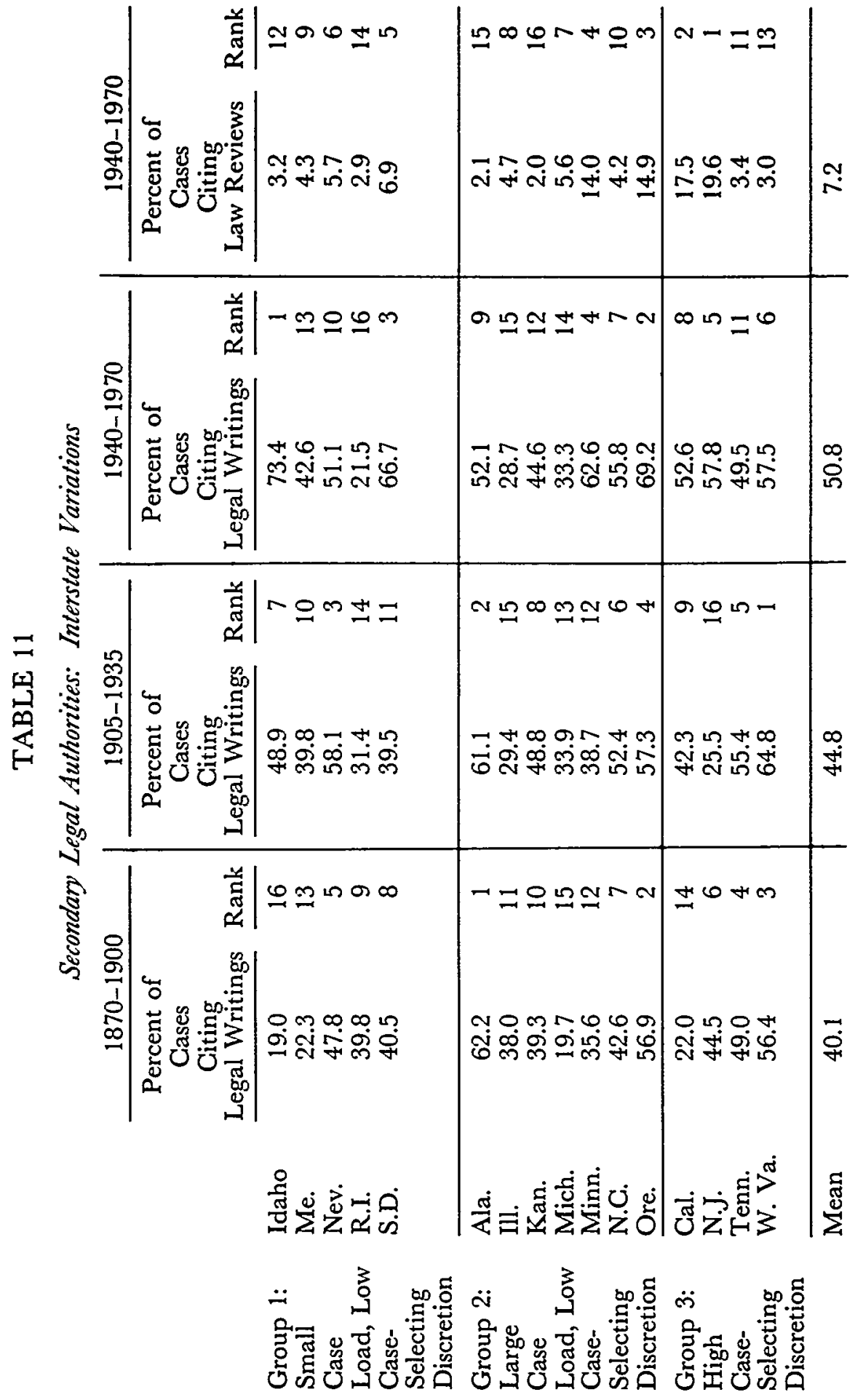


Court, the leader among our 16, cited law reviews in more than onethird (34.9\%) of its sampled cases. ${ }^{90}$

Law review citations in a third of a court's decisions does not mean, of course, that law reviews influence one-third of the decisions. Many citations are relegated to footnotes. A great many are perfunctory, or are used only as a handy source of cases; in a 1915 Kansas case the court remarked (in the midst of discussing a point of law) that: "Two very recent cases, one on each side of the question, are cited in 13 Michigan Law Review, 346, 347."' The court then went on to discuss the two cases.

Law reviews vary greatly in quality, style, and content. Many are narrowly "legal" or "technical." A few articles, to be sure, are broader in scope, or have absorbed concepts and findings from other fields of human knowledge. By citing law reviews, a court can perhaps bootleg "nonlegal" premises into its decisions, or deal with "legal" considerations broader than those usually dealt with. One example, out of many, was Hammond v. Great Atlantic $\mathfrak{E}^{\circ}$ Pacific Tea Co. , a workmen's compensation case. ${ }^{92}$ Honora Hammond, the plaintiff, worked as an executive secretary for the A\&P in Newark. The company had a parking lot for employees next to its building. The adjoining street and sidewalk were in bad condition. One day, in 1966, Mrs. Hammond left work and walked toward the corner to wait for her ride. On the way, she fell and was injured. Did her injury arise "out of and in the course of employment?" In its opinion, the New Jersey court cited an article in the Nebraska Law Review, Workmen's Compensation: Half Century of Judicial Developments. ${ }^{93}$ The author of the article argued that employees injured coming from or going to work should recover compensation. The court quoted a passage from the article, which spoke about liberal rules of recovery in many placesIsrael, France, Germany, and New South Wales. In the end, the court approved compensation for Mrs. Hammond's fall.

Neither the court nor the lawyers had the time or the know-how, we presume, to examine the experience of the world's legal systems on this issue. The Nebraska Law Review conveniently filled them in; it made inaccessible information accessible. It also legitimized the foreign sources. Citing a law review is common and acceptable. Citing foreign sources is rarer and more dubious.

90. See note 95 infra.

91. Williams v. Wessels, 94 Kan. 71, 77, 145 P. 856, 858 (1915).

92. 56 N.J. 7, 264 A.2d 204 (1970).

93. 41 Neb. L. REV. 1, 51-52 (1961). 
We suspect that among modern cases, those which are more selfconsciously innovative tend to cite law reviews more than others. One such case, Suvada $v$. White Motor $\mathrm{Co}^{94}$ - a case frequently cited in its own right-broke new ground in manufacturers' liability. It cited no less than nine law review articles, along with a number of treatises (Hursch, American Law of Products Liability; Prosser on Torts), and the Restatement of Torts. Many out-of-state cases were also cited. A change in the law, it seems, calls for a broad search for authority. The "big impact" cases in our sample also support this interpretation-the 103 opinions ( $1.7 \%$ of our 5,904 cases) that were cited at least 50 times in later cases contained an average of 31.8 citations to prior cases, compared to the overall mean of 10.2.

Similarly, as Table 11 shows, SSCs which in recent years have been considered innovative-that is, California and New Jerseywere the most prolific citers of law reviews. During 1940-1970, $19.6 \%$ of the New Jersey Supreme Court opinions and $17.5 \%$ of the California opinions cited law reviews, as compared with a 16-state mean of $7.2 \%$. In $1960-1970,34.9 \%$ of the New Jersey opinions cited law reviews; so did $26.2 \%$ of California's opinions. ${ }^{95}$ In the 1905-1935 period, before its constitutional reforms, the New Jersey Supreme Court ranked last among the 16 in citing secondary authority. Merryman, after observing that the California Supreme Court doubled its citation of law reviews from 1950 to 1970 , while cutting its citation of legal encyclopedias by $80 \%$, suggested that when courts focus on new issues and new law, compendia of the old become less relevant. ${ }^{96}$ By the same token, law reviews, especially contemporary ones with their bias toward "law reform," become more relevant. To this extent, law review citation rates may be a rough index of a court's orientation toward an overt policy-making role.

Still, it is striking to see how conservative citation patterns are, even in decisions of great public interest and consequence. An important New Jersey case of 1970 upheld the newly created Mortgage Finance Agency. ${ }^{97}$ This body had power to sell tax-exempt bonds to private investors, and funnel the money into the mortgage market for

94. 32 Ill. $2 \mathrm{~d} 612,210$ N.E.2d 182 (1965).

95. Oregon and Minnesota also were far above average in citing not only law reviews, but also other legal writings. In 1960-1970, $23.8 \%$ of Oregon opinions and $18.4 \%$ of Minnesota's cited law reviews. The 16 -state mean was $11.9 \%$.

96. Merryman, Toward a Theory of Citations, supra note 1, at 405-07. For our sample, New Jersey (at $57.8 \%$ ) and California (52.6\%) were only slightly above the 16 -state average $(51.1 \%)$ in citations to all legal writings.

97. New Jersey Mortgage Fin. Agency v. McCrane, 56 N.J. 414, 267 A.2d 24 (1970). 
home loans. The court cited statutes and cases, mostly from New Jersey, and a 1970 state report, Housing Crisis in New Jersey. It is likely that the judges mulled over what the law meant, socially, economically, and politically, and what impact their decision would have, one way or the other. But if background and impact were considered, the court kept quiet about it. The decision, on the surface, was entirely "legal." Note, however, that unlike the Illinois case that widened manufacturers' liability, the New Jersey case upheld the current law, which here took the form of a recent statute. The case legitimized what was on the books already. In this role, perhaps, "legal" citations will do. ${ }^{98}$ Even in a liberal, activist court with caseselecting discretion, most demands for change (either "left" or "right") are rejected; and this means that the court's opinions will not (overtly) include a far-ranging search for authority.

Merryman's study of authorities cited by the California Supreme Court documents the generally conservative scope of citations, even on a "liberal" court. ${ }^{99}$ Merryman found that in 1970 the court frequently cited its own prior opinions (1,832 times) or California IAC opinions ( 1,120 cites), but cited other state courts infrequently (259 cites). It did cite federal cases 835 times; this came to $19 \%$ of all citations. Citations to secondary authorities-337 cites in all-accounted for only $7.5 \%$ of all citations. About half of these were to law reviews. The court cited restatements of the law 14 times, encyclopedias 25 times, and annotations 19 times. There were 115 citations to all other authorities, including treatises and nonlegal sources. Merryman lists all those cited three or more times in 1970. There was the merest handful of "outside" authorities. Only one was not a law book-and that was Webster's Dictionary. Four sources were local treatises. Three were general treatises (e.g. , Corbin on Contracts, Prosser on Torts). The Encyclopedia of the Social Sciences was cited once; so was Mencken's The American Language. The court referred to one newspaper article.

We have gone into some detail, because one might well have guessed that, over the years, citation patterns would broaden considerably, that judges would pay more attention to social science, and

98. This, of course, also reflects the current state of doctrine, which generally calls for judicial restraint in reviewing economic legislation. Compare, however, Muller v. Oregon, 208 U.S. 412 (1908), where the lawyers who wanted the Court to uphold a social welfare law passed by a legislature felt compelled to provide reams of legal and social science data in the famous "Brandeis Brief." This was to give ammunition to the Court to use in validating legislation concerning maximum hours of employment.

99. Merryman, Toward a Theory of Citations, supra note 1. 
that they would take in a wider range of premises and more diverse knowledge as food for decisionmaking. Obviously, some courts have become more "activist." Our data, however, suggest that while the judges may be absorbing broad learning at the present time, any such learning is hardly reflected in citation patterns. This rarity is reflected by the great fuss which was made over one footnote in Brown v. Board of Education which cited, in support of the decision, a number of social science studies. ${ }^{100}$ Whether the readings cited actually influenced the outcome is very doubtful. In any event, SSCs rarely go outside the law for authority. ${ }^{101}$ Social science, economic, or technical studies were cited in only $0.6 \%$ of the 1940-1970 SSC cases. Granted, judges read books and absorb ideas, values, and concepts from their reading, from everyday life, from movies, radio, and television. They are exposed to popular versions of scholarly findings, and sometimes to the findings themselves. These do not show up as such in the body of their opinions. Old habits of citation persist, no doubt, because judges still feel that only "legal" authorities are legitimate.

\section{CONCLUSION}

The New Jersey mortgage finance case and our negative findings concerning citation of "nonlegal" authorities point up the central theme of our findings. The SSCs have cited more and more cases in their opinions. Their opinions have grown longer and more elaborate. Since 1960, they have looked more often to "change-oriented" legal writings such as law reviews, and less often to treatises that crystallize the teachings of the past. Dissents and separate concurrences more often mark their opinions, further undermining the classical facade of appellate law.

But these trends, for the most part, have been gradual movements, not headlong stampedes. The trends are somewhat more pronounced in cases that are "important," as measured by frequency of subsequent cites. On the whole, the style of SSCs is rather conservative, at least in the typical case. Judges cling, it appears, to a nine-

100. 347 U.S. 483, 494 (1954). See, e.g., Cahn, Jurisprudence, 30 N.Y.U.L. REv. 150 (1955); Garfinkel, Social Science Evidence and the School Desegregation Cases, 21 J. PoL. 37 (1959).

101. SSCs also rarely cite legislative reports. Only $1.6 \%$ of the cases did so, even in 1940-1970. New Jersey and California were highest, citing such reports in $6.9 \%$ and $4 \%$ of their cases, respectively. The sparseness of recorded state legislative history, of course, helps explain this fact. 
teenth-century style; they depart from it as little as they can, and only when they must.

To be sure, there is great variation state by state. Generally speaking, the big-state SSCs (California and New Jersey), which control the cases they hear, show the newer traits most strongly. More and more SSGs have adopted the California and New Jersey court structure and jurisdictional rules in recent years. But our findings concerning the effect of court structure are masked and confounded by too many exceptions for comfort. The patterns are not entirely clear; the interstate differences are not always great; the behavior of many SSCs is not easily predictable or explainable on the basis of our quantitative data. As is often the case with matters of form and style, they respond less swiftly and obviously and uniformly to social change than matters of substance do. In any event, style and citation patterns are matters of "judicial culture." Explaining individual state variations requires knowledge of the idiosyncratic legal culture of the states in question, a task largely beyond the resources of the present study. 